\title{
Mi recuerdo de Monseñor Romero
}

\author{
Jon Sobrino, \\ Centro de Reflexión Teológica, \\ San Salvador, El Salvador.
}

En los años que han transcurrido desde la muerte de Mons. Romero he publicado varios escrilos sobre su persona y su obra. Son escritos analíicos sobre su figura como creyente, profeta, mártir, arzobispo y salvadoreño. Al acercarse pronto -el año que viene- el décimo aniversario de su asesinatomartirio he pensado que sería bueno volver a escribir las mismas cosas pero desde otro punto de vista, si se quiere, usando otro género literario: mi recuerdo personal de Monseffor Romero. De esta forma quisiera colaborar a preparar la celebración del $\mathbf{X}$ Aniversario $\rightarrow$ preparación que ya está en marcha - para que 1990 sea un anto importante de celebración, de recuerdo, de esperanza y de compromiso en El Salvador, en América Latina y en todo el mundo.

Me he decidido por el género literario de "recuerdos" para comunicar ante wodo que Mons. Romero fue algo muy real, algo que "hemos visto, oído y tocado." Quisiera reafimmar que Mons. Romero no es ni solo un concepto analizable ni un mito venerable, sino que fue verdadera carne salvadoreña y cristiana, y que es hoy espiritu viviente y vivificante, salvadorefio y cristiano también. Esto sólo se puede hacer "recordando," cada uno a su modo, lo que fue Mons. Romero.

"Recordar," adernás, tiene otra ventaja, pues no significa sólo actualizar voluntaristamente lo que se ha registrado en la memoria, sino que es tener memoria de algo que nos ha impactado hondamente, que está dentro de nosotros de manera activa, que nos sale siempre al paso como fuente de inspiración y ánimo en el presente y en los momentos importantes de nuestra vida. Un recuerdo nos acompanta siempre porque se ha hecho parte de nosotros.

Desde este punto de vista me parece muy importante que todos cuenten sus 
recuerdos de Mons. Romero, de modo que quedemos inundados por muchos recuerdos de muchas gentes, sobre todo de los recuerdos de los pobres, los que mejor "lo vieron, oyeron y tocaron" y los que más hondamente lo llevan en su corazón.

Como ayuda al lector de estos recuerdos quisiera esclarecer desde el principio que no he pretendido escribir una biografia, aunque fuese una biograffa personalizada por mí, de Mons. Romero, ni siquiera una minibiografía. He recogido más bien, entre numerosos recuerdos, sólo aquellos que han sido más impactantes para $\mathrm{ml}$ y que después me han dado más que pensar. Por eso me extiendo en mis recuerdos más tempraneros, los de los tres primeros meses de su ministerio como arzobispo de San Salvador y en los de sus últimos días. Los tres afios que van entre una cosa y otra sólo los he recogido resumiéndolos con el término "coherencia" y ejemplicándola con su "opción por los pobres," por el pueblo salvadoreño y pueblo de Dios.

Estos recuerdos que ofrezco tienen un cierto orden cronológico, pero no en sentido estricto. A proposito de cosas importantes que ocurrieron al principio de su ministerio he ido extrapolando reflexiones sobre la totalidad de su vida y de su obra. Así, con ocasión de ciertos recuerdos he intentado presentar cosas fundamentales de Mons. Romero: su conversión, sus dificultades intraeclesiales, su teología, su liderazgo eclesial y popular, su experiencia de Dios...y, por otra parte, el impacto de su vida y muerte en el pueblo salvadorefo y en todo el mundo. Son pues recuerdos, pero recuerdos reflexionados, salvadoreftizados y teologizados. Como contrapartida, me ha sido imposible evitar algunas repeticiones, pues he optado por ofrecer reflexiones ocasionales, más que una presentación sistemática, que he intentado hacer en otros escritos.

Digamos para terminar que la razón última de escribir estos recuerdos es el agradecimiento que tantos sentimos hacia Mons. Romero, y yo también personalmente. Siempre hay muchas razones para hablar y escribir; pero una razón importante y forzosa es el agradecimiento. A la larga no puede haber un agradecimiento mudo, anónimo, que no tome la palabra. Y ciertamente seria ingratitud callar sobre Mons. Romero.

Estos recuerdos pretenden esclarecer, además, puntos importantes de la figura de Mons. Romero. Es cierto que casi todo lo que decimos es conocido, pero la interpretación ha sido, a veces, discutida Por decirlo claramente, quisiéramos contestar la interpretación que se ha dado - sobre todo en algunas curias - de que Mons. Romero hubiera sido un hombre bueno y virtuoso, pero dependiente y manipulable. De mis recuerdos no se puede sacar esa conclusión sino más bien la contraria: en último término más influyó Mons. Romero en muchos, en mi, que nosotros en el. 
Por último, con estos recuerdos queremos cooperar a seguir haciendo presente a Mons. Rometo en todas partes y especialmente en El Salvador. El silencio oficial que se ha cernido sobre Mons. Romero no sólo es tristemente sorprendente e injusto, sino sumamente empobrecedor para la Iglesia y el país.

Recordar a Mons. Romero es una necesidad, y por varias razones. En El Salvador, dada la pirámide de edad, la mitad de la población prácticamente no lo conoció, y es bueno que quienes lo invocan hoy como "San Romero de América" —en palabras de Pedro Casaldáliga - lo conozcan como el Monsefior Romero histórico, como el que hablo, actú, luchó y murio, como "el que pasó haciendo el bien y fue asesinado a manos de los impíos." Pero es sobre todo una necesidad porque Mons. Romero tiene hoy, aun en situaciones coyunturalmente distintas, mucho que aportar a la Iglesia y al país, y tiene algo que aportar que nadie más aporta. Por eso la finalidad última de este escrito es poner a producir el esplritu de Mons. Romero para el bien del país y de la Iglesia, de la paz y de la justicia, de la fe y de la esperanza.

San Salvador, 24 de marzo, 1989.

Mi primer encuentro personal con Mons. Romero fue el 12 de marzo de 1977. En la tarde de ese dla el P. Rutilio Grande, S. J. y dos campesinos, un niffo y un anciano, fueron asesinados cerca de El Paisnal. A la noche, en el convento de Aguilares, estábamos muchos jesuftas, sacerdotes, religiosas y centenares de campesinos que lloraban a Rutilio, al sacerdole que les había anunciado la buema noticia del evangelio.

Alli estŕbamos esperando a Mons. Romero, quien había tomado posesión de la arquidiocesis pocos días antes, el 22 de febrero, y a su obispo auxiliar Mons. Rivera, para celebrar la primera eucaristla ante los cadáveres de los tres asesinados. Se iba haciendo tarde y los obispos no llegaban. La gente se iba impacientando y la noche aumentaba el nerviosismo. Entonces el P. Jerez, provincial de los jesultas en Centroamérica, decidió comenzar la eucaristía. Todos se dirigieron a la iglesia, pegada al convento, pero yo me quedé - no recuerdo por qué- rezagado. Tocaron a la puerta del convento, la abrl y entró Mons. Romero con Mons. Rivera. El rostro de Mons. Romero estaba serio y lleno de preocupación. Lo salude, y sin decir palabra lo llevé hasta la iglesia. Ese fue mi primer contacto personal con Mons. Romero. Fue breve, sólo simbolico, pero la ocasión to hizo muy importante para ml.

Indudablemente, en aquelios momentos nuestro pensamiento estaba puesto en Rutilio y en los campesinos asesinados. A todos nos venía a la mente lo que podrí pasar en el futuro; pues, aunque ya había comenzado la represión contra los campesinos y algunos sacerdotes ya habían sido capturados y expulsados 
del país, el asesinato de un sacerdote era algo inaudito en El Salvador. Se empezaban a romper no ya las reglas del bien, sino las reglas del mal. Cualquier cosa podía pasar en el país si los poderosos se habían atrevido a asesinar a un sacerdote. De hecho, 1977 lue un año muy duro para los campesinos, para los sacerdotes y también para nosotros los jesuílas. Dos meses después expulsaron del país a los tres jesuítas que quedaron en Aguilares y el 20 de junio todos los jesuítas fuimos amenazados de muerte.

Lo más importante de aquella noche era, pues, el cadáver de Rutilio; pero para mi fue también muy importante ver el rostro serio y preocupado de Mons. Romero. Aquel obispo, de quien yo sólo sabía que había sido muy conservador y débil psicológicamente, comenzaba su ministerio arzobispal no en medio de celebraciones solemnes, sino en medio de capturas, torturas, expulsión de sacerdotes y, ahora, en medio de la sangte de uno de los sacerdotes a quien mejor había conocido: Rutilio. Y, lo peor, en medio de una creciente represión a campesinos y obreros que los obispos, molivados especialmente por Mons. Rivera, habian denunciado valientemente en un mensaje del 5 de marzo.

El rostro serio y preocupado de Mons. Romero cuando le abrí la pueria me atrajo desde aquel momento, y para mis adentros pensé que tenía que ayudarlo. Ya en las reuniones del clero de los últimos días de febrero, en las cuales se presentó como nuevo arzobispo y en las cuales nos pidió ayuda en medio de las graves dificultades, nos hizo modificar la idea que teníamos de él. La decisión de ayudarle fue espontánea y compartida por muchos. Era también una necesidad para todos nosotros, pues barruntábamos que las cosas se iban a poner muy difíciles y era mucho mejor enfrentarlas unidos como Iglesia que separados y divididos. Ya había habido, pues, un cambio notable en las relaciones entre Mons. Romero y nosotros. Pero aquella noche del 12 de marzo fue decisiva. Y la verdad es que el cambio fue sorprendente, pues mis escasas relaciones con él fueron más bien tensas desde que regresé a El Salvador en 1974.

Lo único que yo sabia entonces sobre Mos. Romero es que era un obispo muy conservador, muy influenciado por el $O p u s ~ D e i$, contrario -a veces con agresividad intelectual- a los sacerdotes y obispos que habían aceptado la línea de Medellín. Tenía también por marxistas y politizados a varios de los jesuítas de El Salvador, precisamente a aquellos de quienes yo estaba aprendiendo a dar mis primeros pasos como jesuía y teólogo, después de siete aflos de ausencia.

Creo que la primera vez que vi a Mons. Romero en persona fue en 1974 en el seminario San José de la Montana donde di una charla, a sacerdotes y seminaristas sobre el Jesús histórico y el reino de Dios, si mal no recuerdo. En las filas de adelante y a mi derecha estaba Mons. Luis Chávez, el anterior arzobispo, Mons. Rivera, su auxiliar, y Mons. Romero, entonces también su 
auxiliar.

Lo que entonces me impresionó fue que Mons. Romero estaba allí, por fidelidad a su arzobispo, supongo, pero que no levantó la cabeza durante mi charla, como no queriendo avalar, sino distanciarse de lo que yo decía. En pocas palabras, yo debía ser para Mons. Romero otro de los sacerdotes marxistas; y, yo a mi vez, me convencí de que Mons. Romero era tal como lo habían pintado.

Todo esto se confirmó el 6 de agosto de 1976. Este día se celcbra la fiesta del Divino Salvador, patrono del país, y se tiene siempre una solemne misa. En aquellos años se invitaba a una importante personalidad eclesial a que tuviera la homilía en presencia de todos los obispos, gobiemo, cuerpo diplomático, etc. Solía ser, pues, una homilía importante. Por cierto, si se me permite un paréntesis, la homilía de 1970 la uvvo el P. Grande, reconocido y querido sacerdote de la arquidiócesis y candidato a rector del seminario. En su homilía, Rutilio comentó las tres palabras que aparecen en la bandera nacional: Dios, unión, libertad. Su homilfa fue una gran denuncia de cómo estaba el país, sin unión y sin libertad, y, por lo tanto, sin Dios. La homilía causo una gran sorpresa y un gran impacto; y a Rutilio no le hicieron rector del seminario. Pues bien, en 1976 el orador sagrado elegido para la ocasión fue Mons. Romero, quien fungía ya como obispo de Santiago de Maria. Yo no asistí a la misa del 6 de agosto, pero pocas horas después de concluida la misa, un sacerdote me trajo la grabación de la homilia. La escuché y me quedé de piedra. En le primer punto de la homilía Mons. Romero criticó las cristologías que se producian en el país, cristologias racionalistas, cristologías que llaman a la revolución, cristologías con odio... En otras palabras, su homilia fue una fuerte crítica contra mi cristologia.

Se comprenderá que nosotros no viéramos con buenos ojos que Mons. Romero fuera el sucesor del arzobispo Luis Chávez, obispo pastoral, muy cercano al pueblo y con quien teníamos muy buenas relaciones. Para mí también el candidato ideal era Mons. Rivera. Pero no fue así. El 8 de febrero venía yo de México, y en el avión de TACA vi una gran foto de Mons. Romero en la portada de un periódico salvadorefo. El nuevo arzobispo de San Salvador era Mons. Romero. Pensé que se avecinaban malos tiempos. Me pregunté si Mons. Romero tendría el coraje de denunciar la represión o si, por el contrario, la facilitarla; si defenderia a los campesinos y sacerdotes amenazados. Pocos días después recibr una tarjeta postal de un jesufta mexicano poco menos que dándome el pésame. La verdad es que todos veíamos un panorama muy sombrio. Afortunadamente todos nos equivocamos.

Estas cosas que ahora recuerdo no tenfan, por supuesto, ninguna importancia aquella noche del 12 de marzo. Ni a Mons. Romero ni a mí se nos pasó por la cabeza la homilía del 6 de agosto. Pero pensándolo después, aquel 
primer saludo en silencio fue para mí como una especie de reconciliación con Mons. Romero, el comienzo de una nueva relación eclesial y de una amistad. Sé que a muchos les ocurió lo mismo, y todos nos alegramos; pues, aunque algunos opinan que los sacerdotes avanzados, los teólogos de la liberación, las comunidades de base, sólo buscan relaciones táclicas con la jerarquía, no es asl. Para todos es una alegría vivir en la Iglesia como hermanos, también -y especialmente cuando es posible- con los hermanos obispos.

Otro pensamiento empezó a rondarme por aquel entonces, aunque sólo tiene importancia en lo personal. Yo sabía que Mons. Romero tuvo la humildad y delicadeza de disculparse por su actuación anterior. A una comunidad de base llegó a pedirles perdón, aflos más tarde, por lo que les dijo en 1972 prácticamente justificando la militarización de la universidad nacional y la represión que origino. También pidió perdón a un companfero jesuíta que era rector del seminario cuando los obispos -entre ellos, con fuerza, Mons. Romero- dicidieron que los jesuílas abandonasen la dirección del seminario. Y asi, otros casos de humildad y delicadeza

No sé por qué me perturbaba la idea de que algún día Mons. Romero sacase a relucir sus ataques contra mí y se disculpase. Afortunadamente, nunca habló de eso; y me alivio. Sin embargo, recuerdo un día, creo que a finales de abril de 1977, cuando Mons. Romero me vio en una esquina de catedral y vino a hablarme. "Le agradezco," me dijo, "la reflexión que usted ha hecho sobre la Iglesia. Creo que ha ayudado mucho." Se refería al dossier que él llevó a Roma explicando la situación del país y la actuación eclesial después de la muerte de Rutilio. Yo habla colaborado en la parte de reflexión teológica.

La verdad es que Mons. Romero no necesitaba agradecer nada para que yo, y tantos otros, nos pusiéramos a su servicio. Pero me gusí su gesto, pues era una especie de aceptación eclesial hacia lo que haciamos y, sobre todo, una muestra de confianza. Esa delicadeza la tuvo siempre Mons. Romero. Siempre que le ayudé en algo, bien fuera en la publicación de Medellín y Puebla o con las reflexiones teológicas que hacía para su uso, Mons. Romero me envió una carta o una pequefta nota de agradecimiento.

\section{II}

Volvamos a la noche del 12 de marzo. Después de la misa, Mons. Romero nos pidió a los sacerdotes y religiosas que nos quedásemos allí con él; y ambién se quedaron algunos campesinos, lacos, sin ninguna discriminación, por supuesio. Tuvimos una reunión allí mismo y a altas horas de la noche, sin esperar al día siguiente después de algún descanso. A Mons. Romero se le notaba nervioso, abrumado por la responsabilidad y como sin saber exactamente qué hacer ante un hecho tan inaudito. La pregunta que nos hizo fue elemental: qué debemos y qué podemos hacer como Iglesia ante el 
asesinato de Rutilio.

En medio de su nerviosismo y turbación, yo percibf que él estaba dispuesto a hacer lo que fuera necesario, aunque el solo pensarlo probablemente le causaba espanto, pues le había llegado la hora de tener que enfrentarse con los poderosos, la oligarquía y el gobiemo. Y lo que ciertamente recuerdo es que las palabras con que nos pedía ayuda eran totalmente sinceras, le salian del corazón. Un arzobispo nos pedía ayuda de verdad. Y pedía ayuda a aquellos a quienes semanas antes había tenido por sospechosos, marxistas... Ese gesto de diálogo y de humildad me produjo una gran alegria. Y yo pensaba que aunque aparentemente todo empezaba tan mal para Mons. Romero, en realidad comenzaba bien. Comenzaba el germen de una Iglesia unida, decidida y clarividente, que tanto crecería despues. Sentí un gran carifio por aquel obispo humilde que nos pedía, casi mendigaba, ayuda para soportar la carga que se le venia encima, muy superior a la que podian llevar sus hombros y los de cualquier otro.

Sentí también, o al menos intuí, que algo profundo estaba pasando en su interior. Ciertamente estaba nervioso; pero en medio del nerviosismo y el no saber qué hacer de aquellos primeros momentos, yo cтeo que Mons. Romero hizo una honda decisión de reaccionar como Dios se lo pidiera; hizo una opción verdadera por los pobres, representados aquella noche por centenares de campesinos alrededor de tres cadáveres, indefensos ante la represión que ya sufrían y la que preveían. No se si interpreto bien lo que pasaba en aguellos momentos por el corazón de Mons. Romero, pero creo que debio experimentar que aquellos campesinos habían hecho una opción por él, le estaban pidiendo que él los defendiera. Y la respuesta de Mons. Romero fue la de hacer, el, una opción por los campesinos, convertirse en su defensor, en la voz de los sin voz. Yo creo que aquella noche se empezó a gestar definitivamente la conversión de Mons. Romero.

Y la verdad es que a Mons. Romero no le gustaba mucho que se hablase de su "conversión;" y no le faltaba algo de razón. Solla recordar que provenía de una familia humilde, que nunca había estado cerca de la riqueza y la abundancia, sino de la pobreza y la austeridad. Además, todos reconocín que su anterior vida sacerdotal y episcopal había sido notablemente virtuose A su modo, habla estado abierto a los pobres e incluso los habla defendido en Santiago de Marla con ocasión de la represión. Nadie tenía, pues, a Mons. Romero por hombre malo, irresponsable o doblado. Incluso en su época más conservadora, se podia hablar con el de cosas delicadas por su altura tica. Creo, pues, que Mons. Romero siempre mantuvo un corazón limpio y una reserva ética que no lograron sofocar ni su ideología consevadora ni la actuación retrógrada de una buena parte de la jerarquía de la que él formaba parte. Lo que ocurria es que su personalidad interior estaba desdobladai en su 
corazón mantenía los ideales religiosos, aceptaba las directrices del Vaticano II y Medellín; pero su mente interpretaba la novedad del concilio y de Medellín desde una postura muy conservadora, con temor ante todo lo que pudiera inmiscuir a la Iglesia en la came conflictiva y ambigua de la historia. Ese desdoblamiento interior creo yo que es lo que se fue disolviendo aquella noche, y creo que se le puede llamar conversión; no tanto como un dejar de hacer el mal para hacer el bien, sino como un radical cambio en captar y poner por obra la voluntad de Dios. Esa voluntad de Dios se le debió presentar muy novedosa ante los tres cadáveres y ante los centenares de campesinos que ponían en él sus ojos que, sin palabras, le preguntaban que iba a hacer.

Llámese o no conversión, el radical cambio de Mons. Romero es de las cosas que más ha impactado a todos y a mí también personalmente. Mons. Romero tenía entonces 57 años, edad en que los hombres ya han fraguado su estructura psicológica y mental, su comprensión de la fe, su espiritualidad y su compromiso cristiano. Además, acababa de ser nombrado arzobispo, es decir, estaba constituido en máxima autoridad y responsable de la institución eclesial, que, como toda institución, inclina más a la continuidad y a la prudencia, cuando no a la marcha atrás. Por último, las circunstancias históricas no le eran nada favorables. Mons. Romero fue muy consciente desde el principio de que él había sido el candidato de la derecha, y desde el principio sintio los halagos de los poderosos quienes le ofrecieron la construcción de un palacio episcopal, esperando que cambiase la línea de su predecesor Luis Chávez y González. Cambiar, y cambiar radicalmente, significaba no sólo defraudarlos $\rightarrow$ recordemos que Mons. Romero no aceptó ningún palacio episcopal, sino que vivió los primeros meses en un cuartito del Hospital de la Divina Providencia junto a la sacristía一, sino enfrentarse con ellos. Lo que se le venía encima a Mons. Romero, si cambiaba, eran las iras de los poderosos, de la oligarquía, del gobierno, de los partidos políticos, del ejército y los cuerpos de seguridad; y, después, de la mayoria de sus hermanos obispos, de varios dicasterios vaticanos y hasa del gobierno de Estados Unidos. En un balance de fuerzas para explicar su conversión, Mons. Romero tenía a su favor a un grupo de sacerdotes y religiosas y, eso sí, el dolor y la esperanza de todo un pueblo; en su contra estaban todos los poderosos. El balance de fuerzas estaba evangélicamente a su favor, pero históricamente en su contra. Si Mons. Romero se lanzó por caminos muy nuevos, a su edad, desde la cúspide de la institución y teniendo tanlas cosas en contra, es que su conversión fue muy real, llegó hasta lo más profundo de su ser, lo configuró para siempre y lo llevó hasta entregar su vida. El cambio extemo de conducta, innegable y reconocido por todos, tuvo que provenir de un cambio interior muy hondo y muy real.

¿A qué se debió la conversión de Mons. Romero? Esta pregunta me la han hecho infinidad de veces. No tengo ninguna respuesta técnica-psicológica, ni nunca hablé de ello personalmente con él. Tampoco es fácil para nadie entrar 
en lo más prolundo de otra persona, y en el fondo sería presunción pretender hacerlo. Pero, con todo, quiero exponer mi propia visión de la conversión de Mons. Romero, aunque no sea más que para insistir en que realmente se dio ese cambio en su vida interior y en que sus actuaciones externas no pueden ser explicadas por la manjpulación a que hubiera sido sometido.

Creo que la ocasión de la conversión de Mons. Romero - que fue también luz y ánimo para sus nuevos caminos- fue el asesinato de Rutilio Grande. Mons. Romero conoció muy bien a Rutilio, lo consideraba como sacerdote ejemplar y como amigo; tan es así que Rutilio ejerció como maestro de ceremonias en su consagración episcopal. Sin embargo, Mons. Romero no compartía la pastoral de Rutilio en sus antos de Aguilares; le parecía demasiado politizada, demasiado horizontal, alejada de la misión fundamental de la Iglesia y peligrosamente cercana a las ideas revolucionarias. Rutilio fue, pues, para Mons. Romero un "problema;" más aún, un "enigma." Era, por una parte, sacerdote virtuoso, celoso, verdaderamente creyente; y, por otra parte, su misión pastoral le parecía incorrecla y equivocada. Ese "enigma," pienso yo, es lo que se le esclareció con el asesinato de Rutilio. Creo que ante el cadáver de Rutilio a Mons. Romero se le cayó la venda de los ojos: Rutilio tenía razón. El tipo de pastoral, de Iglesia y de fe que promovió Rutilio Grande son las verdaderas. Más hondamente aún, si Rutilio murió como Jesús, si mostró el mayor amor de entregar su vida por los hermanos, es que también su vida y su misión habían sido como las de Jesús; Rutilio había sido un insigne seguidor de Jesús. En resumen, no era Rutilio Grande, sino él, el equivocado; no era Rutilio quien debiera haber cambiado, sino él Oscar Romero. Y estas rellexiones que, en teoría, pudieran haber quedado en puro raciocinio, se tradujeron en decisión de cambiar, de proseguir él la línea de Rutilio y, sobre todo, el camino de Jesús. Ante un cadáver, como dice san Ignacio en la contemplación de los pecados delante de Cristo crucificado, la pregunta decisiva es "qué voy a hacer por Cristo." Creo que la muerte de Rutilio fue lo que sacudió a Mons. Romero y le dio la fuerza para un nuevo hacer; y que la vida de Rutilio le dio la dirección fundamental también a su propia vida, aunque él, por su propia situación personal como arzobispo y por las circunstancias históricas cada vez más críticas, fuese concretando esa dirección. En aquellos días se hablaba de la conversión de Mons. Romero como del "milagro de Rutilio."

Una segunda cosa que debió impactar pronto a Mons. Romero en aquellos primeros días fue la diferente reacción de los diversos grupos eclesiales. Mons. Romero sabía que su nombramiento no había sido bien acogido, que los sacerdotes de pastoral más avanzada, las comunidades de base y todos los que trabajaban en la línea concientizadora y liberadora de Medellín lo habían acogido con temor. Y conocía también las expectativas que había despertado su nombramiento entre los católicos acomodados —aquellos que estaban a veces en connivencia con los grupos de poder que habian atacado y calumniado al 
anciano Mons. Chávez - y entre un grupilo de sacerdotes en esa órbila. Pues bien, la sorpresa de Mons. Romero debio ser muy grande al ver que, en esos días tan duros para él y en los cuales se corrían riesgos reales, los primeros lo acuerparon y los segundos lo abandoraron. A la hora de la verdad, aquellos a quienes el habla tenido por sospechosos, con quienes se había peleado y a quienes incluso había acusado y condenado, estuvieron con él. Los otros, los que él juzgaba piadosos y ortodoxos, los prudentes y no politizados, los aparentemente fieles a cualquier indicación de la Iglesia, lo dejaron solo, como los discípulos a Jesús; y pronto comenzaron a criticarlo, atacarlo y desobedecerlo (con lo cual mostraban además que su repetida fidelidad a la jerarquía eclesí́stica terminaba cuando el arzobispo no era de su agrado y las cosas se ponían peligrosas).

Todo esto le dio mucho que pensar a Mons. Romero. No se deducía de ahi que todo lo que hacían los sacerdotes avanzados era ya perfecto; pero sí se deducía, al menos, que tenían mucha más verdad y mucho más amor cristiano que los otros. Sea cuales fueren las ideas teológicas y polílicas de esos sacerdotes, en aquellos momentos Mons. Romero vio claro que ellos estaban decididos a acuerparlo en denunciar la barbarie del país, lo cual mostraba que eran honrados con la trágica realidad salvadoreña, no como los otros que la ignoraban $y$ la justificaban. $Y$ que estaban decididos a correr riesgos personales, a hablar y denunciar públicarnente, aunque en aquel entonces eso supusiera ser seftalados, capturados o asesinados. Ese mínimo de verdad y de compromiso no lo encontró en el otro grupito. Estos se callaron y justificaron su silencio, como meses antes lo hubiese hecho el mismo Mons. Romero, por el bien de la Iglesia. Como trágico ejemplo, recuerdo la carta circular del cardenal de Guaternala, Mario Casariego, a sus sacerdotes en la cual les venía a decir que Rutilio Grande se habla buscado su muerte por meterse en donde no debia, y que sus sacendotes no siguieran ese ejemplo.

Esa direfente reacción le impactó mucho a Mons. Romero. Recuerdo que una tarde, pocos días después del asesinato de Rutilio, me encontré con él en la YSAX - la radio del arzobispado, tan conocida porque retransmitia las homilfas de Mons. Romero y porque tantas veces la dinamitaron- y me mostró una carta, en papel lujoso y, si no recuerdo mal, adomada con dibujos de flores. La carta era de una persona que había estado cercana a Mons. Romero. En ella le mostrabe su sorpresa por el cambio y no compartía su nueva actuación. Mons. Romero no se mostró para nada afectado. Recuerdo que me dijo simplemente: "Es de una persona del Opus." Y lo que creo que me querfa decir es que "no entiende, como tampoco yo entendía antes."

Lo que unos y otros hicieron y no hicieron esos días ayudo a Mons. Romero a ver mas a cambirx. En sintesis, se podrin formular as: cuando las coses se ponen críticas, no se puede repetir que uno es cristiano y abandonar la 
historia; uno no se puede refugiar en el cristianismo para no ser salvadoreño. Los que abandonaron al país a su tragedia, amparándose en su ser cristianos, ya no fueron luz para Mons. Romero. Los que optaron por el país, por decir la verdad, por denunciar las atrocidades y comprometerse con la justicia -aun con limitaciones y exageraciones- se convintieron también en luz para Mons. Romero.

Una tercera cosa que explica la conversión de Mons. Romero, la definitiva y la que lo mantuvo hasta el final en lidelidad a la voluntad de Dios, fueron los pobres de su pueblo. Muy pronto le mostraron aceptación, apoyo, cariño y amor. Probablemente no se lo esperaba cuando fue nombrado arzobispo; pero es ciero que los pobres esperaban un arzobispo tal como él lo fue. Y es que, como dije antes, en El Salvador, como en tantos otros lugares de América Latina, antes que la Iglesia hiciese una opción por los pobres, los pobres habían hecho una opción por la Iglesia, al no encontrar ni en los gobiemos, ni en las fuerzas amadas, ni en los partidos políticos, ni en la empresa privada nadie que los defendiera.

En cuanto Mons. Romero dio sus primeros pasos, sus primeras denuncias, sus primeras visitas a las comunidades, los pobres se volcaron hacia él, entraron en su corazón y entraron para quedarse. Y Mons. Romero entró lambién en su corazón, en donde se ha quedado hasta el día de hoy.

No voy a extenderme en este punto tan conocido y tan público. Sólo quiero affadir que Mons. Romero debí encontrar en los pobres aquello que el profeta Isaías dice del siervo sufriente de Jahvé y san Pablo de Cristo crucificado: en ellos hay luz y hay salvación. El sufrimiento de los pobres tuvo que ser una gran sacudida para Mons. Romero, al ver sobre codo la creciente represión. Los pobres le exigieron conversión; pero, al ofrecerle también luz y salvación, se la facilitaron. Y eso lo reconoció Mons. Romero. Para mí no hay duda de que ahí está el último secreto de Mons. Romero, y así lo dijo. En una de sus más logradas palabras, palabras de esas que no se pueden inventar si no se llevan de verdad en el corazón, dijo: "con este pueblo no cuesta ser buen pastor."

\section{III}

En los dfas posteriores al asesinato de Ruilio, la curia arzobispal y toda la arquidiócesis pasaron por momentos de gran ebullición los cuales marcaron un camino a Mons. Romero, quien lo recorrió hasta el final sin dar marcha atrás. Muy pronto comprendió que como arzobispo tenía que explicar al pueblo lo que es la Iglesia, su denuncia profética y la defensa de los pobres. $Y$ ese mismo afio escribio dos cartas pastorales sobre la Iglesia.

Esas grandes convicciones que empezaban a cuajar en su mente las puso por obra En aquellos días publicó una serie de comunicados denunciando la 
represión al pueblo y la persecución a la Iglesia, exigiendo del gobierno la investigación de los asesinatos y prometiendo al pueblo que la Iglesia estaría de su lado, defendiéndolo, denunciando las injusticias, aunque eso le costase la sangre de sus sacerdotes. Como cosa muy especial -que rompia con muchos afios de tradición- Mons. Romero prometió públicamente que no participaría en ningún acto oficial del gobiemo mientras no se aclarasen los crimenes y cesase la represión, Y lo cumplió: en tres afios nunca participó en actos gubernamentales, no los bendijo con su presencia.

Estas primeras actuaciones de Mons. Romero empezaban a mostrar cuál iba a ser su manera de proceder. El tomaba las decisiones de lo que había que hacer después de discutir y dialogar con el clero, las religiosas y los laicos. Recuerdo que una de las reuniones de aquellos primeros días duró desde las ocho de la mañana hasta las ocho de la tarde. Su talante desde el principio fue profélico, denunciando con claridad las aberraciones; fue evangélico, con sencillez, sin dejarse amedrentar por las consecuencias políticas de sus acltuaciones; y fue público, hablando al país, prometiendo cosas que se podian verificar, que se las podian reclamar si no las cumplia.

Entre lo que prometió públicamente, y cumplio, destacaron dos cosas en aquellos días: la suspensión de clases durante tres días en los colegios católicos y una misa única el 20 de marzo. La suspensión de clases no fue una vacación, como protestaron sus detraciores, sino tres días de estudio, reflexión y oración de la Biblia, el concilio y Medellín. Recuerdo que en muy poco tiempo escogimos textos bíblicos, del Vaticano II y de Medellín para ayudar a esa reflexión.

La misa única causo mayor revuelo, y pienso que esta decisición fue muy importante para Mons. Romero, pues lo llevó a tener que confrontarse con su misma fe y empezó a enfrentarlo con la institución eclesiástica. En contra de la misa única en catedral estaba el gobiemo que temía una concentración masiva, como así ocurrio, y estaban los católicos de las colonias ricas quienes, hipocritamente, se quejaban de que de esa forma se les privaria de oír misa y de cumplir con el precepto dominical, sin ocurrírseles, al parecer, que nada les hubiera costado ir en carro hasta catedral, aunque, eso si, allí hubieran tenido que estar tres horas de pie, aguantando el sol y mezclados con los pobres.

Pero incluso Mons. Romero tuvo sus dudas sobre la oportunidad de la misa única. Estaba convencido de que habla que hacer algo importante que llamase la atención del país y sacudiese las conciencias; pero tenla un escrípulo teológico que lo formulo en la reunión con la sinceridad que lo caracterizaba. "Si la eucarista es un acto en que se da gloria a Dios, ¿no será mayor gloria de Dios la multiplicidad habitual de las misas dominicales?" He de reconocer que en aquel momento sus palabras me inquietaron porque dejaban traslucir una teologia trasnochada; pero despues, recapacitando, y en base a coda su 
actuación las interpreté de manera correcta. Mons. Romero eslaba mostrando su sincero interés por las cosas de Dios. Su tcologla era discutible, pero lo que estaba fuera de discusión era su honda fe en Dios, su supremo interés en que en este mundo se le diese gloria.

Con la misma sinceridad con que Mons. Romero expuso su dificulad otros expusieron sus razones teológicas a favor. Hubo una larga discusión hasta que el P. Jerez pidió la palabra y dijo: "Yo creo que Mons. Romero tiene razón en que nos preocupemos por la gloria de Dios. Pero, si mal no estoy, los padres de la Iglesia decian: gloria Dei vivens homo, la gloria de Dios es el hombre viviente."' Con esta intervención se zanjó práclicamnte la discusión. Mons. Romero pareció convencido y aliviado en su escrúpulo y decidió que se tuviera la misa única.

En aquel momento yo sólo pensaba que Mons. Romero habla hecho una lúcida y valiente decisión pastoral, pero después pensé lo que tuvo que significar para Mons. Romero aceptar una nueva formulación de lo que es la verdadera "gloria de Dios." En ello estaba en juego nada menos que su comprensión personal de Dios, su fe en Dios. No se trataba sólo de aceptar una nueva formulación teológica, sino una nueva compresión de Dios. Y Mons. Romero la aceptó. Repitió hasta la saciedad que para Dios nada hay más importante que la vida de los pobres. En Puebla le dijo a Leonardo Boff: "en mi país se está asesinando horrorosamente. Es preciso defender el mínimo que es el máximo don de Dios: la vida." El mismo reformuló la sentencia de san Ireneo, citada por el P. Jerez, como gloria Dei, vivens pauper, "la gloria de Dios, es que el pobre viva" Y a la inversa, bramó contra los ídolos, divinidades falsas, pero muy reales que producen muerte y exigen victimas para subsistir.

Creo que Mons. Romero, no soblo pasó por una conversión sino que a sus 57 afios, hizo, también, una nueva experiencia de Dios. Desde entonces no pudo separar a Dios de los pobres, su fe en Dios de su defensa de los pobres. Creo que vio en Dios el prototipo de la opción por los pobres, lo cual le exigió ponerla por obra él mismo, pero le iluminó también quién es Dios. De ahí que para nada lo asustaran las nuevas formulaciones sobre Dios: Dios de vida, Dios del reino, Dios de los pobres, que asumía con toda naturalidad. Le gustó mucho el gloria de la misa salvadoretha donde se canta al Dios de la vida y se condena a los dioses del poder y del dinero.

Este descubrimiento, costoso y gozoso, del Dios de los pobres no lo llevó para nada a empequeflecer lo que creo que fue una constante en toda su vida: el misterio de Dios. Desde los pobres descubrió que Dios es de ellos, es su defensor y liberador, entre los pobres descubrió que Dios es el Dios empequeffecido, oculto, sufriente y crucificado. Pero esto lo hizo ahondar también en el misterio de un Dios siempre mayor, transcendente, la última reserva de verdad, de bondad, de humanidad, con que contamos los seres humanos. No se 
si Mons. Romero conocía la continuación de la frase citada de san Ireneo: vita ausem hominis, visio Dei, "y la vida de los seres humanos es la visión de Dios." Pero si no con éstas, sí lo comunicó con otras palabras. Personalmente, me impactó hondamente - $y$ he intentado plasmarlo en mis escritos- la fe en Dios de Mons. Romero, su absoluta convicción de la realidad de Dios, su absoluta convicción de que el misterio de Dios es salvífico para los hombres, que es bueno que haya Dios y que hay que alegrarse de que haya Dios. El 10 de febrero de 1980, en una situación ya caótica, él en plena confrontación con el gobierno, ejército, oligarquía y Estados Unidos, Mons. Romero fue una vez más el profeta valiente e implacable, el que hablaba de las cosas de este mundo y el que salía en defensa de su pueblo oprimido. Pero en esa misma homilía, con la misma naturalidad con que pronunciaba sus denuncias históricas, dijo las siguientes palabras: "¡Quién me diera, queridos hermanos, que el fruto de esta predicación de hoy luera que cada uno de nosotros fuéramos a encontramos con Dios y que viviéramos la gloria de su majestad y de nuestra pequefiez!... Ningún hombre se conoce mientras no se haya encontrado con Dios."

Quien dice estas palabras tiene una profunda experiencia de Dios. En nombre de Dios, Mons. Romero defendió la vida de los pobres; y cuando quería ofrecernos a todos lo mejor que el tenía, nos ofrecía simplemente a Dios.

El Dios de los pobres y el misterio de Dios es lo que Mons. Romero hizo presente a todos aquellos que quisieron escucharlo. Así revalorizó a Dios en nuestro país. Lo escucharon los pobres, por supuesio, — ly qué les queda muchas veces si no es su fe en Dios?-; lo escucharon no creyentes, quienes respetan al menos el nombre de Dios; lo escucharon los dubitantes, agradecidos de que Mons. Romero les iluminara lo que se les habia oscurecido.

Con Mons. Romero se ha hecho imposible repetir en el país la grave acusación, tan repetida en la Escritura: "por causa de ustedes se blasfema el nombre de Dios entre las naciones." Pero se ha hecho posible mucho más. Recuerdo que Ilalo López Vallecillos, ilustre escribr salvadoreño, ya fallecido, me dijo una vez: "siempre le he dado vueltas al misterio de Dios. Cuando era pequefio una abuela mía es la que me hacía pensar en él. Ahora, ese misterio se me ha hecho presente en Monseñor Romero."

\section{IV}

Esa inmensa fe de Mons. Romero, siempre antigua y siempre nueva, es lo que se estaba gestando en aquellos días. Sin que nadie lo pretendiera, con ocasión de la misa única en catedral a Mons. Romero se le hizo la pregunta más última que se le puede hacer a un ser humano: en qué Dios cree. Su decisión por la misa única fue la expresión de una nueva fe, aunque en la 
superficie pareciera sólo una valiente decisión pastoral para unos y una provocación política para otros.

Pero esa decisión significó lambién un primer enfrentamiento serio de Mons. Romero con ciertos estamentos de la institución eclesial, problema que padeció durante tres años.

E] alboroto que causó el anuncio de la misa única fue tal que Mons. Romero dicidió comunicárselo personalmente al nuncio, y me pidió que lo acompañara junto con otros sacerdotes. El nuncio no estaba y nos recibió su secretario. Desde el principio vi al secretario de la nunciatura visiblemente enojado por la misa única y no hizo ningún esfuerzo por ocultarlo, aun delante de Mons. Romero, siendo él sólo un simple secretario y Mons. Romero el arzobispo de San Salvador. Allí experimenté un poco del autoritarismo que con frecuencia se da en las curias de todo tipo y la incomprensión ante el sufrimiento del pueblo y ante la situación de un arzobispo abrumado por tan serias responsabilidades. Creo que ése fue uno de los dias en que he sentido mayor indignación.

El secretario comenzó diciendo que la argumentación pastoral y teológica en favor de la misa única era buena; creo que incluso dijo que muy buena. Esto me sorprendi6, pues, en mi ingenuidad, no veía cómo compaginar palabras tan laudatorias con su visible enojo. "Pero," añadió, "ustedes han olvidado lo más importante." No se me ocurría qué podía ser más importante en aquellos momentos, pero el secretario sentencio: "han olvidado el aspecto canónico." Yo no podía creer lo que oía, ni ninguno de los que allí estábamos. Le contesté que nada hay más importante que el cuerpo de Cristo que estaba siendo reprimido y desangrado en el país; que nada había más importante para la Iglesia en esos momentos que denunciar la represión y dar esperanza al pueblo; que los aspectos canónicos eran secundarios en estas ocasiones, y le recordé aquello de Jesús de que el sábado es para el hombre. Pero todo fue en vano, y hubo que argumentar también canónicamente. Por fortuna, algunos de los sacerdotes allí presentes mostraron que también en el aspecto canónico Mons. Romero había actuado correctamente. No creo que el secretario quedó convencido, pero allí terminó la discusión.

Fue una hora larga y muy desagradable, pero lo que más me impresionó es que Mons. Romero no dijo ni una sola palabra en todo ese tiempo. Parecía estar como distante de aquella discusión leguleya, pensando más en el cadáver de Rutilio, en los campesinos asesinados, en el miedo y el dolor de la gente. Al terminar la reunión, sin levantar la voz, sin entrar en la discusión de los argumentos, dijo más o menos estas palabras. "El país está pasando por una situación excepcional y la Iglesia tiene que poner un signo excepcional de denuncia y de evangelización. Yo soy el responsable de la arquidiócesis y vamos a tener la misa única." Y nada más. Cuando salíamos de la nunciatura 
yo estaba Lodavía muy alterado, mientras Mons. Romero mostraba normalidad y paz. "No entienden," me dijo lacónicamente refiriéndose a la nunciatura.

El 20 de marzo se tuvo la misa única y fue un éxito pastoral sin precedentes. En la plaza de catedral estaban presentes decenas de miles de personas: rezaron, cantaron, comulgaron, recibieron ánimo en su fe y en su esperanza. Antes de la misa, varios sacerdotes estuvimos confesando. Recuerdo que varias personas me dijeron que era su primera confesión después de varios años y que tenían necesidad de volverse a Dios después de lo de Rutilio. Incluso medido por el criterio tradicional de la confesión, la misa única fue un gran éxito pastoral. Pero la nunciatura seguía sin entender.

Con esta misa comenzó también un largo calvario de incomprensión y de rechazo jerárquico para Mons. Romero. Es cierto que en mayo de 1977 los obispos salvadoreflos publicaron un mensaje que podía considerarse todavía como de apoyo a Mons. Romero, pero de ahf en adelante todo fueron dificultades con los obispos salvadorentos y con varios dicasterios romanos. En El Salvador, sólo Mons. Rivera le fue fiel.

No creo que nadie de buena voluntad y en su sano juicio pueda dudar de la fidelidad de Mons. Romero a la Iglesia, al Vaticano II, a Medellín y Puebla, a las enseflanzas de los papas y a la doctrina social de la Iglesia, como lo muestran sus homilias y cartas pastorales. Una de sus mayores alegrías era, precisamente, ir a Roma a encontrarse con el papa, contarle la realidad del país y de la Iglesia salvadoreña, recibir de él orientación y ánimo, y advertencias si era necesario. Deseaba grandemente estar en comunión con Roma. Recuerdo el júbilo con que regresó de su primera visita a Pablo VI, quien estrechándole las manos, le dijo coraggio, ánimo. También regresó satisfecho de su segunda visita a Juan Pablo II, aunque de la primera - como lo cuenta en su diariosalió triste y decepcionado, pues el papa, al parecer mal informado, no lo comprendió bien. Personalmente, creo que Juan Pablo II fue evolucionando en su aprecio por Mons. Romero, hasta llegar a alabarlo públicamente, como pastor y márir que dio la vida por amor a Dios y el servicio a sus hermanos.

A lo largo de tres aftos Mons. Romero tuvo en contra a los obispos salvadoreffos quienes, en público y en duros informes privados al Vaticano, lo criticaron. En Puebla, Mons. Aparicio -el mismo que nos acusó públicamente a los jesuitas de ser causantes de la violencia en el pais, y eso estando alll el $P$. Arrupe- dijo a unos periodistas que Mons. Romero era un irresponsable al hacer peligrar a toda la Iglesia enfrentíndola con el gobierno, y que acuraba por vanidad para convertirse en el Jimmy Carter de América Latina. Del Vaticano le enviaron tres visitadores en año y medio, para asombro de los salvadoreños que se preguntaban cuándo enviarian un tan solo visitador a diócesis sin ningún plan pastoral y, a veces, favoreciendo las actuaciones de un ejército criminal. En Roma, sus relaciones con el cardenal Baggio fueron muy 
tensas. El cardenal le hablo hasta de la posibilidad de que le nombraran un administrador apostólico - con plenos poderes-, ante lo cual Mons. Romero solo pidió que lo hicieran con dignidad para que no sufriera su pueblo, aunque no créa que eso fuera solución. Una vez, el cardenal Baggio le recibió en su despacho con estas palabras: "está usted en mala compañía" y le mostró un libro que tenfa sobre su escritorio. El libro, publicado por UCA Editores, recogia su tercera carta pastoral y la primera de Mons. Rivera y junto a sus nombres aparecían en la portada los de I. Ellacuria, T. R. Campos y el mío.

Mons. Romero descubrió, pues, y cuando menos lo esperaba, las limitaciones, las intrigas y las pequefleces de la institución eclesial. Lo que le costaba entender era que, mientras el país ardía en llamas y hasta los sacerdotes eran asesinados, no encontrase apoyo sino oposición; que cuando lo que estaba en juego era el reino de Dios, los obispos salvadorefios se preocupasen de que nada le pasara a la institución. Eso lo hizo sufrir mucho y en su última época sentla verdadero disgusto de asistir a las reuniones de la conferencia episcopal pues alli se hablaban dos lenguajes totalmente distintos.

En el último retiro espiritual de su vida, un mes antes de su asesinato, escribió de su putto y letra las cosas que más le preocupaban y que comunicó a su confesor, el P. Azcue, S. J. Una de ellas era "mi situación conflictiva con mis hermanos obispos." De la plática con el P. Azcue debió salir muy confortado y escribio:

Me orientó mucho esta consideración: si me critican mi actuación pastoral, ¿qué otra altemativa me proponen? Y me he confirmado que lo único que interesa es la radicalidad del evangelio que no wodos pueden comprender. Que se puede ceder en algunos aspectos accidentales, pero no se puede ceder en seguir radicalmente el evangelio. Esta radicalidad siempre tiene que traer contradicciones y hasta divisiones dolorosas.

En medio de ese sufrimiento Mons. Romero encontraba alivio y fuerza en su fe y en el inmenso carifio de la gente. También le consolaba - como lo cuenta en su diario- conversar en Roma con el cardenal Pironio o con el P. Amupe - "es un santo," dice en su diario- o con el cardenal Aloysio Lorscheider cuando lo visitó en San Salvador. Pero la cruz era muy pesada, y de ello cai en la cuenta con mucha claridad en Puebla.

Estuve en Puebla, junto con otros teólogos y científicos sociales, para seguir más de cerca un acontecimiento tan importante y para ofrecer ayuda a los obispos que nos la solicitaran, pues no fuimos invitados a participar oficialmente. Pues bien, una tarde tuvimos una reunión, conjunta nuestro grupo y un buen número de obispos que vinieron a visitamos. Juntos tratamos los temas más importantes de Puebla, juntos cenamos y juntos rezamos. Y allí estaba Mons. Romero. Se lo veía contento y a gusto. Por su modo de ser, las 
aulas de la conferencia no eran su lugar natural. Más a gusto se sentra entre los campesinos; y, en Puebla, más a gusto se sentía entre los periodistas hablándoles de El Salvador que en los pasillos del Seminario Palafox, con su ambiente de política eclesial y de diplomacia Hacia el final de nuestra reunión, alguien sugirió que los obispos de Puebla -el grupo que lo deseasoescribiesen carlas de solidaridad a los obispos de las arribuladas Iglesias de Centroamérica, en concreto a las de El Salvador, Guatemala y Nicaragua Se escribieron las cartas y las fimaron varios-obispos, con la excepción de la carla dirigida a Guatemala, pues los obispos guatemaltecos allf presentes juzgaron más prudente no recibir esa pública muestra de solidaridad. Recuerdo que Mons. Romero estaba emocionado, por todo. Por la fraternidad de la reunión, por la sinceridad de nuestras discusiones, por el ambiente de fe y de Iglesia, y, sobre todo, por el carifo y solidaridad que le mostraron los obispos. Casi con lágrimas en los ojos dijo: "me he encontrado como hermano entre otros hermanos obispos."

\section{$\mathbf{V}$}

Estos son mis recuerdos más importantes de Mons. Romero en sus primeros meses, aunque he ido antadiendo reflexiones sobre su posterior trayectoria. Resumiendo, creo que Mons. Romero pasó por un proceso de conversión y que, relativamente pronto, encontro el nuevo camino que recorrió hasta el final. No sé cuánto tiempo le llevo; no sé si su conversión fue como la caida del caballo de san Pablo o como el período de movimiento de espíritus que cuenta san Ignacio de Loyola Pero muy pocos meses despues de su nombramiento como arzobispo, Mons. Romero era un obispo, un cristiano y un salvadorefio muy distinto.

En breve tiempo Mons. Romero tuvo que aprender a tomar, él mismo, importantes decisiones y a dialogar con sus sacerdotes; tavo que aprender serenidad para no agravar la situación y valentia para denunciar y enfrentarse con los poderosos; tuvo que aprender a dar una esperanza al pueblo y a rocibir del pueblo su sufrimiento, su fe y su compromiso. Eso es lo que se notaba en su exterior. En su interior twvo que aprender su fe en el Dios de los pobres y en el Dios mayor que todo, mayor que sus ideas previas y mayor que la misma Iglesia que empezaba a convertísele en cruz. Tuvo que aprender que nada hay más importante que el reino de Dios, la vida, la esperanza, el amor, la fraternidad. Tuvo que aprender que el lugar de la Iglesia es el sufrimiento de los pobres, la realidad de los pueblos crucificados, verdadero siervo de Jahve, como él dirfa después. Tuvo que aprender no sólo a dar, sino a recibir luz y salvación de ese pueblo crucificado. Y lo aprendió.

Nunca hablé de estas cosas con Mons. Romero, pero supongo que ese aprendizaje, como el de Jesús, fue también doloroso. Yo creo que Mons. 
Romero forcejé con Dios, como Jacob, y que pasó por el desierto, como Jesús. Más de una vez pediría a Dios que pasara el cáliz y se pondría ante él con los gemidos y llantos del verdadero sacerdote de la Cara de los Hebreos.

Pero creo también que la conversión le originó una inmenza paz, una inmensa liberlad y un inmenso gozo. El hombre más bien tímido de carácter, con una salud débil que lo forzaba a buscar descanso físico y psicológico, se convirtió en hombre fuerte. No recuerdo que en aquellos tres afios estuviese enfermo o tuviese que ausentarse para un descanso psicológico. Su trabajo aumentó extraordinariamente, pero no rehuyó ninguna de las innumerables exigencias de su cargo ni rechazó las innumerables peticiones que le hacían. Al contrario, siempre lo vela animado a hacer cosas nuevas, nuevos proyectos, nuevos temas para cartas pastorales. La hermana Teresa, ya fallecida, su ángel de la guarda en el hospitalito, le repetía con frecuencia que no trabajase tanto. Lo vefa en su cuartito a altas horas de la noche y Mons. Romero le contestaba que todavla no había rezado el rosario. Era en vano intentar frenar su ritmo. Mons. Romero fue un trabajador infatigable y con una fuerza que sorprendió a todos.

Creo que el evangelio que redescubrio en aquellos dias se le hizo exigencia, pero tambien fuerza. Nunca lo ol quejarse de sus sufrimientos ni lamentarse de exceso de preocupaciones. Con la fuerza del evangelio, acompatando al pueblo y acompanado por el pueblo, recorrío su ministerio arzobispal hasta el final, hasia el altar de la capilla del hospitalito.

Y to recorrió con gozo. Para mi Mons. Romero es la persona que ejemplifica más cabalmente unas geniales palabras de $\mathbf{K}$. Rahner: "el evangelio es una pesada carga ligera, que cuanto más la lleva uno más es llevado uno por ella." La conversión puso una gran carga sobre los hombres de Mons. Romero, pero esa misna carga se le volvió ligera, le dio ánimo, empuje, liberad y gozo.

\section{VI}

Tres meses después de su nombramiento, Mons. Romero era ya un obispo distinto, cambiado, mientras arreciaba la represión y el miedo. En el mes de mayo de 1977 se agravó la situación del país y se institucionalizó la persecución a la Iglesia. El 1 de mayo fue capturado un joven jesuíla. Una semana después se lo entregaron al provincial y a Mons. Romero. Este le ofreció su laza de café y se negó a firmar un acta en la cual se decía que el joven jesulta no habla sido maltratado. El 11 de mayo asesinaron al P. Alfonso Navarro. De nuevo, una gran misa y una importante homilía de Mons. Romero. Comparo la situación del país con una caravana perdida en el desierto; al beduíno que les mostraba el camino correcto lo asesinaron. El 19 de mayo el ejército entró en Aguilares, expulsó a los tres sacerdotes jesuílas, 
profanó la Iglesia y el sagrario y militarizó el pueblo. Nadie pudo entrar en Aguilares, ni siquiera el nuncio. Muchísimos campesinos fueron asesinados.

La represión y la persecución iban en aumento, pero para entonces Mons. Romero ya tenía una idea clara de lo que habia que hacer, una accitud decidida y un liderazgo notable entre los sacerdotes. Eso es lo que mostró excepcionalmente el 19 de junio.

Después de un mes de militarización, el ejército desalojó el pucblo de Aguilares. Mons. Romero decidió ir cuanto antes a Aguilares para denunciar las atrocidades cometidas y sobre todo para acompañar y dar esperanza a un pueblo aterrorizado. Muchos fuimos con él, y fue un día que, personalmente, nunca olvidare.

Se me quedaron muy grabadas las palabras con que comenzo la homilía: "a mí me toca ir recogiendo atropellos, cad́́veres y todo eso que va dejando la persecución de la Iglesia." ¿Qué definición tan nueva, tan ưágica y lan acertada del ministero espiscopal!, pensé. Afios después Mons. Romero acuñaría su célebre "pastoral de acompañamiento," pero aquel día lo formuló con máxima historicidad; como también lo hizo hacia el final de su vida, en febrero de 1980, cuando un periodista le preguntó que haria la Iglesia si estallase una guerra y él le contestó que se mantendria furme "aunque sólo sea recogiendo cadáveres e impartiendo la absolución a los moribundos." La opción por los pobres, tan exigida por Puebla, cobraba en estas palabras una inmensa radicalidad que la alejaban de toda rutina y de la pura palabrerfa. Es verdad, pensé, que Mons. Romero ha hecho una opción por su pueblo sufriente.

En la homilia de ese día también denunció proféticamente a quienes "convirtieron un pueblo en una cárcel y en un lugar de tortura." Por lo que yo recuerdo esa fue la primera homilia, a la que siguieron muchas otras, que por el contenido, por la valentía y por el vigor de sus palabras mostró a Mons. Romero como un auténtico profeta. Aftos después, en 1980, un reconocido especialistr en los profetas de Israel, José Luis Sicre, me dijo: "yo creo que a lo largo de la historia habrá habido sólo unos ocho o diez auténticos profetas en la línea de la tradición biblica: Amós, Isaías... Mons. Romero es uno de ellos."

También mostró en la homilía esa nota tan característica suya de agradecer a todos los que le ayudaban y prestaban servicios a la Iglesia Agradeció a los jesuítas el trabajo de Rutilio Grande y de sus companteros sacerdotes. Y agradeció a las religiosas Oblatas del Sagaado Corazón, quienes -dando notable ejemplo de valentia, pues ningún sacerdote se atrevia a trabajar alli en esos dias - se encargaron de la parroquia de Aguilares.

Recuerdo también, y es lo que más me impactó de su homilia, el gran amor que Mons. Romero mostraba hacia aquellos campesinos de Aguilares, sufrien- 
tes y atemorizados por lo que habían vivido en el último mes. ¿Cómo mantener la esperanza de ese pueblo? ¿Cómo devolverles dignidad, al menos, en su sufrimiento? ¿Cómo decirles que ellos son lo más importante para Dios y para la Iglesia? Mons. Romero lo dijo con estas palabras: "ustedes son la imagen del Divino Traspasado, del que nos habla la primera leclura." Ustedes son hoy el Cristo sufriente en la historia, vino a decirles. Y en otra homilía de finales de 1979, que también recuerdo bien, hablando del siervo de Jahvé decía Mons. Romero que nuestro liberador, Jesucristo, tanto "se identifica con el pueblo, hasta llegar los intérpretes de la Escritura a no saber si el Siervo de Jahvé, que proclama Isaías, es el pueblo sufriente o es Cristo que viene a redimimos." Decir a unos campesinos auribulados que ellos son hoy el Cristo presente en la historia, y decírselo con sinceridad, es la coma más radical que tiene un cristiano para devolverles, al menos, su dignidad y mantenerlos en la esperanza.

Y Mons. Romero prosiguió. "Sufrimos con los que han sufrido tanto. Sufrimos con los que estál. perdidos, con los que están huyendo y no saben qué pasa con su familia.. Estamos con los que sufren las torturas..." Estoy con ustedes, les dijo Mons. Romero. Y aquel pueblo de Aguilares le creyó. Ese milagro no ocurre todos los días, pero era verdad. Aquellos campesinos de Aguilares se le metieron en el corazón a Mons. Romero y alli se quedaron para siempre. Y Mons. Romero se metió también ell el corazón de lodos los salvadorefios, pobres, sencillos, sufrientes; y en ellos está hasta el día de hoy.

Mons. Romero amó de verdad a su gente. Los amó y sólo los amó. No hizo como otros que, aun amando al pueblo, buscan también sus propios intereses personales, partidistas, eclesiales. Mons. Romero los amó y por ese amor relativizó todo lo demás, amriesgó todo - hasta lo institucional de la Iglesia- y su propia vida Por ello, Mons. Romero fue y sigue siendo fuente de esperanza, de ánimo y de consuelo para todos los salvadorefios que sufren.

Después de la misa salimos en procesión por la plaza del pueblo, en desagravio por la profanación que los soldados hablan hecho del cuerpo de Cristo sacramentado y del cuerpo viviente de Cristo, los campesinos asesinados. En frente de la alcaldía habia varios efectivos armados, con mirada hosca y amenazante hacia nosotros. Al acercarse a la alcaldía, la cabeza de la procesión se detuvo. Estŕbamos preocupados y hasta temerosos, pues no sabíamos qué es lo que podria pasar. En ese momento, espontáneamente, nos volvimos a mirar hacia el final de la procesión donde venía Mons. Romero con el Santísimo en sus manos. Mons. Romero dijo "adelante" y así lo hicimos. La procesión transcurrió sin incidentes, y en ese momento, simbólicamente, Mons. Romero se convirtió en líder de los salvadorefios. Ni lo pretendió ni lo buse6, pero así fue. Mons. Romero era el que iba delante de nosotros. Se fue convirtiendo en punto de referencir de la Iglesia y del país. Nada importante pas6 desde 
entonces en el pais sin que lodos se volvieran hacia Mons. Romero.

He dicho antes que ese día fue muy importante para mí personalmente. Vi a Mons. Romero agigantado y empecé a verme a mí mismo empequeñecido ante él. Ya he contado cómo desde el principio intenté colaborar con él en todo, poniendo mis saberes y mi tiempo a su servicio. iQué menos podía hacer en aquellos momentos tan trágicos y con un arzobispo recién nombrado, abrumado por la responsabilidad y que pedía ayuda con tanta humildad! Sin embargo, he de reconocer que en las primeras semanas pensaba que yo era el que ayudaba a Mons. Romero y que él era el ayudado, que mis ideas teológicas le podrían ser útiles a él, más que a mí las suyas. Y creo que no sólo yo, sino muchos otros, teníamos la misma sensación. No se trataba de quererlo manipular, sino de ayudarle; además, muy pronto Mons. Romero mostró su propia autonomía evangélica. Pero algo quedaba todavía de que lo nuestro era ayudar a Mons. Romero. Pues bien, en aquella misa y procesión de Aguilares empecé a ver las cosas de manera muy distinta: no era yo el que ayudaba a Mons. Romero, sino que era él quien me ayudaba; no era yo el que tenía que ensentar a Mons. Romero, sino que era él quien nos enseñaba.

Mons. Romero ya iba por delante de nosotros; no por su autoridad formal de arzobispo, sino por el peso evangélico y salvadorefó de su actuación. No quisiera que estas palabras sonasen a falsa humildad. Mons. Romero siguió pidiendo y esperando de nosotros que lo ayudásemos de mil formas. Así lo hicimos, y creo que nuestra ayuda fue también provechosa para él. Pero en lo fundamental, Mons. Romero se nos habfa adelantado. No era ya el arzobispo recién nombrado, nervioso y abrumado, sino el que marcaba el camino, con él a la cabeza, $y$ en las cosas más fundamentales.

Y también recuerdo de aquel día el impacto que me causó Mons. Romero para mi propia teología. La forma como celebró aquella eucaristía fue para mí reveladora; fue también -aunque ni él ni yo pensísemos entonces en esocomo una clase de teología. En aquella celebración fueron apareciendo los temas tradicionales de la teología de la eucaristía: la acción de gracias, la palabra, el sacrificio, la presencia de Cristo, las ofrendas, la comunidad... Todos estos temas teológicos eran de sobra conocidos, pero Mons. Romero los elaboro in actu con tanta verdad y con tanta creatividad que me esclarecleron qué es la eucaristía mejor que largos anos de estudio. Desde entonces Mons. Romero fue también fuente de inspiración teológica, como lo expresé en un discurso cuando la Universidad Centroamericana "José Simeon Cafas" (UCA) le otorgó a Mons. Romero un doctorado honoris causa en teologia

He de reconocer, con sinceridad y agradecimiento, que su vida, su obra y su palabra -escuchada ésta desde aquéllas- han sido para mi luz e inspiración teológicas. Creo que sin Mons. Romero no hubiese podido formular teologicamente cosas tan fundamentales como el misterio de Dios, la Iglesia de 
los pobres, la esperanza, el martirio, la solidaridad, el evangelio como lo que verdaderamente es: buena noticia, y la figura de Jesucristo, cuyos tres aftos de vida y misión, cruz y resurrección me han sido iluminados por los mismos tres años de Mons. Romero. También Mons. Romero me hizo pensar - sin entrar ahora en una discusión teórica- en la necesidad de usar la realidad actual como argumento teológico. Todo té́logo sabe que para hacer teología hay que usar la escritura, la tradición, el magisterio, etc. Pero empecé a pensar que hay que usar también la realidad para esclarecer contenidos teológicos. ¿Qué es esperanza?, ¿qué es martirio?, ¿qué es un obispo?, ¿qué es profecía?... Estas y otras cosas se me han iluminado desde él y desde otros, es decir, desde la realidad.

Con Mons. Romero hablé varias veces sobre cosas de teología, y él se mostraba muy interesado. Su interés era ponerla al servicio de la misión de la Iglesia, pero la apreciaba grandemente como cosa importante en sí misma. Al poco de comenzar su ministerio me dijo que la Iglesia estaba reaccionando pastoralmente ante la persecución y el martirio, pero que era necesario también una reflexión teológica. Me pidió que escribiese sobre eso, y así lo hice. Y me encontré, por cierto, con que no había muchos textos que esclareciesen teológicamente lo que era la persecución y el martirio tal como ocurrían en EI Salvador. Tuvo que empezar a argumentar teológicamente con la realidad. También me pidió que reflexionase sobre la Iglesia y su misión, sobre la evangelización y la Evangelii nuntiandi de Pablo VI - sobre la cual organizo tres días de estudio para los sacerdotes. Junto con otros, abordamos los temas candentes del país, las organizaciones populares, la violencia, la misión de la Iglesia ante cosas tan concretas. Recuerdo las numerosas y largas reuniones de Mons. Romero con analistas sociales, sacerdotes en la pastoral y télogos; las discusiones, las explicaciones que pedía Mons. Romero, las correcciones de los diversos borradores, y su decisión final. Antes de ir a Puebla me llamó tres veces para tratar los puntos teológicos más importantes que abordarían los obispos. Recuerdo, por cierto, que me preguntó por qué algunos té́logos de la liberación criticaban la doctrina social de la Iglesia. Traté de explicarle y distinguir los problemas teóricos que plantea la doctrina social de la Iglesia y su uso pastoral. Pero lo que más me llamó la atención es que hacla la pregunta con loda paz, con ganas de entender las cosas, sin sentirse obligado como arzobispo a defenderla por principio, ni muchos menos por apuntarse a lo que esuviera de moda en toologia. Hablaba con naturalidad de estos problemas.

Hablamos, pues, hastante de leologia Lo que Mons. Romero nunca supo o lo que en su humildad nunca se le ocurrio es que con sus preguntas, con sus planteamientos y, sobre todo, con su palabra y su vida me ayudó mucho a hacer teologia Quizfís nosotros le ayudamos a el a conceptualizar los problemas teológicos, y mi opinión es que, al nivel de conceptualización, Mons. Romero se mantuvo más bien al nivel de la teología del Vaticano II,

$$
220253
$$


aunque sus contenidos teológicos reales eran también bỉlicos e históricos, y respondían a la mejor intención de la teología de la liberación. Pero él también nos ayudó, y más radicalmente. Su ayuda teológica no estaba al nivel de conceptualización técnica, sino a nivel mucho más importante: el de la inspiración y la luz para ver y tratar mejor las realidades teológicas fundamentales: Dios, visto desde este mundo, y este mundo, visto desde Dios. Dice Gustavo Gutiérrez que la tarea fundamental de la teología de la liberación es cómo decir a los pobres de este mundo que Dios los quiere. $Y$ eso es lo que iluminó con eficacia Mons. Romero.

Si me he extendido en detallar el impacto que Mons. Romeo tuvo sobre nosotros y sobre mí no es por mencionar un detalle biográfico de pura significación personal, sino para salir al paso de la repetida cantinela de que Mons. Romero fue "manipulado." Sinceramente debo decir que, si de manipulación se trata, más nos manipuló Mons. Romero a nosotros que nosotros a él; más nos dio Mons. Romero a nosotros que nosolros a él. Esa es mi convicción, y mi esperanza.

\section{VII}

Desde el día de Aguilares hasla su muerte hablé varias veces con Mons. Romero, en la curia, en el hospitalito, en nuestra casa. Venía a visitamos con alguna frecuencia y se le notaba relajado. Recuerdo que, antes de irse, iba siempre a saludar y agradecer a la seffora que nos hacía la comida, y eso hacía a nuestra cocinera inmensamente feliz.

No voy a detallar todas las cosas que me impresionaron en los casi tres afios que le quedaban de ministerio. Muchas de ellas son bien conocidas: sus homilías dominicales en catedral, sus continuas visitas a las comunidades, sus cartas pastorales, su apertura a dialogar con lodos, también con personas de la oligarquía y de la fuerza armada que iban a visitarle de noche -como Nicodemo- para buscar su ayuda en algún problema personal. Su prestigio nacional e intemacional fue creciendo inmensamente, y también la hostilidad por parte de la oligarquia, el ejército, el gobiemo, los obispos, hasta que cundió la alarma en el mismo gobiemo norteamericano.

Para resumir en una palabra tantas y tantas cosas que hizo en esos años, lo que me impresionó de Mons. Romero fue su total coherencia con el camino emprendido y su fidelidad en proseguirlo. El principio fundamental de su coherencia fue la opción por los pobres; principio teologal, pues Dios se le mostró como el prototipo de esa acción; principio eclesial, pues esa opción dirigió toda la actuación de la Iglesia; principio histórico, pues la opción la fue concretando según fuese cambiando la situación histórica del país. Lo fundamental de ese principio fue mantener la correlación entre Dios y probres, entre Iglesia y pobres. 
Muchos repilen que la Iglesia es para el reino de Dios, que debe hacer la opción por los pobres, incluso que los pobres evangelizan... Pero ¡qué difícil es mantener ese principio básico de la fe y de la eclesiologla! Mons. Romero lo mantuvo hasta el final. No cabe ninguna duda de que anunció la buena noticia a los pobres y de que los defendió hasta el final. Pero con ser esto no muy frecuente y -en la radicalidad con que él lo hizo- excepcional, fue también notable la clarividencia con que expuso la opción por los pobres, la forma como la teorizó y la elevó a criterio de acción, primero y último. En una de sus frases lapidarias dijo: "el dialogante natural de la Iglesia es el pueblo, no el gobiemo," y con estas palabras -y la práclica consecuente- pulverizaba siglos de cristiandad e intentos, siempre recurrentes, de neo-cristiandad. La deseada y buscada armonía entre Iglesia y poderes de este mundo (Estado, fuerza armada, poderes económicos, partidos políticos) no fue para Mons. Romero ningún ideal. En la práctica no era un ideal realizable, por supuesto, pues esos poderes no dejaban de atacar duramente a la Iglesia. Pero no lo era por principio, pues el mundo del poder no es el mundo de la Iglesia. Lo verdaderamente deseable era la armonía, la compenetración de la Iglesia con los pobres. Por ello dijo también lapidariamente: "la Iglesia juzgará de uno u otro proyecto político según le vaya al pueblo." De nuevo, lo novedoso estaba en no juzgar a priori de los proyecios políticos según ideologías, como es habitual en la Iglesia con su debilidad por ideologías demócrata cristianas y su recelo hacia las socialistas; ni mucho menos según los proyectos políticos favorecieran, halagaran o privilegiaran a la Iglesia institucional. Su criterio fue el bien del pueblo, el bien de las mayorías pobres. Ese criterio no era más que la historización para El Salvador de lo que en la Escritura aparece como criterio primero y último de la acción del mismo Dios, de Jesús y del ser humano cabal: la misericordia. Ante un pueblo sufriente en el camino una cosa hay que hacer con absoluta necesidad, subordinando todas las demás a ella: levantarlo de su postración, curarle sus heridas, y acompañarlo hasta su completa sanación. Lo que Mons. Romero recalcó es que el herido en el camino es todo un pueblo y, por ello, su curación deber ser estructural. De ahí que analizara en sus cartas pastorales las raíces estructurales de sus males y los caminos de justicia para la liberación. Eso lo vio Mons. Romero con toda claridad.

Esta misericordia hacia los pobres es la que rezumaba en todas sus actuaciones. Pero además, la relación de Mons. Romero con los pobres no fue sólo de misericordia servicial. Mons.Romero se volcó hacia los pobres para recibir de ellos, aprender de ellos y dejarse dar la buena noticia por ellos. Recuerdo mi sorpresa cuando para elaborar el documento que iba a presentar en Puebla sobre la arquidiócesis envió un cuestionario a las parroquias y a las comunidades - varios de cuyos miembros probablemente no sabían leer ni escribir- perguntándoles a ellos qué pensaban del país y de la Iglesia, cuál creían ellos que era el mayor pecado, quién era para ellos Jesucristo, qué 
pensaban ellos de la conferencia episcopal, del nuncio, de su propio arzobispo. Mi sorpresa - triste sorpresa, pues eso debiera ser normal- es que Mons. Romero preguntara la opinión al pueblo de Dios; pero aumentó cuando Mons. Romero tomó en serio las respuestas. Yo estaba en el equipo que las tabuló y analizo, y lo recuerdo bien. Eso significaba que Mons. Romero estaba realmente abierto a los otros, a dejarse ayudar y enseñar por los pobres. $Y$ lo mismo hizo antes de escribir su cuarta carta pastoral.

Mons. Romero además creyó en su pueblo pobre y se mostraba orgulloso de una Iglesia de ese pueblo pobre, que eso es la Iglesia de los pobres. "¡Ustedes! ¡Una Igleisa tan viva! ¡Una Iglesia tan llena del Espíritu Santo!" No podía oculiar su alegría por esa Iglesia, que eran ellos, los pobres, los campesinos... En plena represión y persecución dijo estas palabras -retóricas, pero verdaderas - que muestran qué pensaba Mons. Romero de esa Iglesia de pobre.

Si alguna vez nos quitaran la radio (lo decía porque ya había sido interferida y dinamilada), nos suspendieran el periódico, no nos dejasen hablar, nos mataran a todos los sacerdotes y al obispo también, y quedaran ustedes, un pueblo sin sacerdotes, cada uno de ustedes tiene que ser un micrófono de Dios, cada uno de ustedes tiene que ser un mensajero, un profeta. ¡Siempre existirá la Iglesia mientras haya un bautizado!

Puede comprenderse el impacto de palabras como éstas en el pueblo. Mons. Romero se fiaba de ellos, se enorgullecía de ellos, los quería. Y Mons. Romero se dejó querer por ellos, cosa aparentemente tan fácil, pero en el fondo bien difícil. " Cómo me da gusto en los pueblecitos que las gentes y los niños se agolpan a uno, vienen a uno!" Al arzobispado llegaban los pobres con gallinitas para Mons. Romero. Me contaron una vez $-\mathrm{y}$ supongo que es cieroque hasta le llevaron una vaca, lo cual causó conmoción y desconcierto en la curia. Le escribían cartitas contándoles sus problemas personales, y Mons. Romero las contestaba. Le enviaban - los pobres- pequentas limosnas, pesos, centavos. En los momentos de tragedia se le entemecían las entrañas cuando eran asesinados amigos suyos. "Para $\mathrm{ml}$ en particular son nombres muy queridos, Felipe de Jesús Chacón, 'Polín,' como llamábamos a Apolinario. Yo les he llorado de veras." Su pueblo le llenó el corazón y Mons. Romero se dejó querer, lo cual es la forma más radical de romper las distancias y las barreras que siempre existen entre los que están arriba y los que están abajo.

Con sus ojos puestos en los pobres juzgaba de las fuerzas políticas y sociales. Porque vela que las fuerzas de la derecha (gobierno, oligarquía, ejército y cuerpos de seguridad, administración de la justicia, la mayoría de los medios de comunicación, embajada de Estados Unidos) oprimían a los pobres, por eso las denunció y desenmascaro y les exigio una radical conversion. Todo esto es bien conocido y no voy a insistir en ello. Pero sí quiero recordar sus relaciones 
con la izquierda. Mons. Romero defendió, apoyó y se alegró de que surgiesen las organizaciones populares, a las cuales llego a declarar "signos de los tiempos." Indudablemente veía en ellas mucha más realidad y representatividad popular que en las otras. "Yo no les llamo 'izquierda,' sino el pueblo," decía. Como responsable del trabajo pastoral insistió en la pastoral de acompaflamiento para que esas organizaciones no sólo fuesen populares, sino que estuvieran imbuidas del espíritu del evangelio.

Pero también las criticó - y por cierto con mayor fuerza y análisis que lo que ocurrí después-, pero no por ser de izquierda, como simplonamente denunciaron los resiantes obispos, como si esto fuera el mayor de los males, sino en la medida en que las veía anti-populares, si se me permite una expresión chocante. Mons. Romero criticó sus divisiones intemas, el afán de hegemonía de una organización sobre otra, el exagerado protagonismo, como si sólo las organizaciones populares pudieran hacer un servicio al pueblo; y, por supuesto, condenó algunas acciones terroristas y algunas tendencias de manipular la religiosidad popular en servicio de la organización. Todo eso veía él que no favorecía a los pobres. Mons. Romero no fue, pues, acrítico ni ingenuo con respecto a las organizaciones. Llegó a advertirles del peligro que tenían de convertirse en ídolo, la más grave adventencia en lenguaje religioso -al capilalismo y a la doctrina de la seguridad nacional los denunció sin ambages como idolatría. Más aún, durante la primera junta de gobierno (15 de octubre de 1979 a 2 de enero de 1980) uvo que enfrentarse a las críticas de algunas comunidades y de algunos sacerdotes que lo acusaban de haber bendicido al nuevo gobiemo. Recuerdo una fuerte discusión entre Rogelio Ponseele, sacerdote ahora en Morazán, y Mons. Romero sobre este punto en una reunión del clero. La discusión fue fuerte y Mons. Romero se manluvo firme. Después, Rogelio lloró cuando asesinaron a Mons. Romero, y escribió de él: "eso es único en la historia de la Iglesia Es un milagro."

Lo que quiero recalcar es que Mons. Romero criticaba a las organizaciones porque con sus yerros perjudicaban al pueblo; y sus críticas pretendian mejorar la acluación de las organizaciones populares para que sirvieran mejor al pueblo. El criterio del bien de los pobres, el criterio del reino de Dios, es el que estaba actuante tanto en su apoyo como en su crílica a las organizaciones populares. Ese criterio es el que lo movía a conocerlas mejor, a invitarlas a que estuvieran presentes en las reuniones del clero para que expusieran sus puntos de vista -inconcebible para los otros obispos, cuya reacción se redujo a condenarlas por ser de izquierda—, a animarlas a su unificación. Cuando se enteró de que las organizaciones populares habian suscrito una plataforma común se alegró de verdad. Lo vio como un paso importanie para el bien de los pobres.

Años más tarde después de su muerte, cuenta Mons. Rivera que habló con Joaquín Villalobos, uno de los cinco miembros de la comandancia general del FMLN. Dice Mons. Rivera que Villalobos mencionó varias veces a Mons. Ro- 
mero, y que comento: "hoy, Mons. Romero nos daría duro, pero nos comprendería. Personalmente creo que tiene razón. Yo creo que Mons. Romero denunciara muchas cosas que hace el FMLN, por supuesto los asesinatos de personas civiles. Pero creo que los comprenderia, no en cuanto movimiento político-militar, sino en cuanto expresión -trágica o esperanzadora según las simpatias- de querer superar el sufrimiento de los pobres, la injusticia permanente, la mentira establecida. Les pediría que mantuviesen esos ideales y les criticarla sus errores, pero sobre todo les pediría - como a todos- que uuvieran ante sus ojos el bien de todo el pueblo.

La coherencia de la actuación de Mons. Romero con el criterio de opción por los pobres ha tenido muchas consecuencias: credibilidad de la Iglesia, aceptación o respeto al menos hacia lo religioso, ánimo y esperanza sobre todo entre los pobres. Pero quiero recalcar un efecto importante. Con Mons. Romero, la Iglesia - y la fe- se hizo salvadorefía y se hizo cristiana. Cuanto más cristianamente se vive la fe, más salvadorefia se hace; y cuanto más radicalmente se vive la realidad salvadorefta, más cristiana se hace la fe. Fe y realidad salvadorefia, Iglesia y país, no son ya dos magnitudes que tienden a debilitarse, sino a potenciarse mutuamente.

Esta convergencia la expresó Mons. Romero con su vida y con su mucrte. Y lo dijo también en clarividentes palabras que hasta el día de hoy producen escalofríos:

Me alegro, hermanos, de que nuestra Iglesia sea perseguida, precisamente por su opción preferencial por los pobres y por tratar de encamarse en el interés de los pobres... Sería triste que en una patria donde se está asesinando tan horrorosamente no contáramos entre las víctimas también a los sacerdotes. Son el testimonio de una Iglesia encamada en los problemas del pueblo... La iglesia sufre el destino de los pobres: la persecución. Se gloría nuestra Iglesia de haber mezclado su sangre de sacerdotes, de catequistas y de comunidades con las masacres del pueblo, y haber llevado siempre la marca de la persecución... Una Iglesia que no sufre persecución, sino que está disfrutando los privilegios y el apoyo de la tierra, esa Iglesia itenga miedo! No es la verdadera Iglesia de Jesucristo.

Una Iglesia cristiana-salvadoreffa o salvadoreña-cristiana es lo que pretendió y consiguio Mons. Romero. El precio a pagar fue grande para la Iglesia: participar en la sangre salvadorefla Pero la recompensa fue también muy grande: en El Salvador los pobres se supieron y se sintieron de verdad Iglesia de Jesús. Hablando de estas cosas en un congreso de teologfa, recuerdo que un sacerdote africano me comentó que lo que más le cuestionaba de las palabras de Mons. Romero, arriba citadas, era que en su pals no habian matado a sacerdotes. El comentario me produjo escalofríos, pero creo que quería decir algo muy importante: la Iglesia cristiana no se hará africana en su país hasta 
que no comparta los sufrimientos y las esperanzas reales de su gente.

Lo que consiguió Mons. Romero con la coherencia de su actuación fue una Iglesia salvadoretla y, por lo tanto, una Iglesia popular. Creo que si viviera hoy le daría mucha tristeza que el término "Iglesia popular" haya venido a significar - porque así lo han determinado desde fuera - algo malo y sospechoso. Mons. Romero seguiria criticando los fallos de los pobres en la Iglesia. Pero se preguntaria, ¿cómo no ha de ser popular una Iglesia de Jesús verdaderamente salvadorefia?

\section{VIII}

La última vez que vi en vida a Mons. Romero fue a mi regreso de una reunión de obispos, teólogos y agentes de pastoral en Sao Paulo, Brasil, en febrero de 1980. Creo que êl también fue invitado a esa reunión, pero prefirió no salir del pais, dada la situación cada vez más alamante. Unas dos semanas antes de su asesinato vino a nuestra casa y le comuniqué los saludos que le mandaban de Brasil, y especialmente las palabras de apoyo de don Pedro Casaldáliga, a quien conocí entonces. El mismo don Pedro le escribió una carta que le llegó a tiempo para leerla Mons. Romero le contestó el 24 de marzo. La cara está escrita a máquina, pero no lleva la firma de Mons. Romero. La debió dictar pocas horas antes de su muerte. Un mes despues, Mons. Rivera tuvo la delicadeza de enviársela a Pedro Casaldáliga, quien la conserva como verdadera reliquia. Como es una de sus últimas cartas, sino la última, la copio literalmente.

San Salvador, 24 de marzo, 1980

Excmo. Sr. Obispo

Mons. Pedro Casaldáliga

Sao Felix-Brasil

Querido hermano en el episcopado:

Con profundo afecto agradezco su fraternal mensaje por la pena de la destrucción de nuestra emisora.

Su calurosa adhesión alienta considerablemente la fidelidad a nuestra misión de continuar siendo expresión de las esperanzas y angustias de los pobres, alegres de correr como Jesús los mismos riesgos, por identificamos con las causas de los desposeldos.

A la luz de la fe, siéntame estrechamente unido en el afecto, la oración y el triunfo de la Resurrecición.

Oscar A. Romero, Arzobispo 
"Alegres de correr como Jesús los mismos riesgos, por identificamos con las causas de los desposeídos." Eso es lo que conscientemente hizo Mons. Romero en los últimos meses de su vida. Hablábamos antes de coherencia en su actuación, ahora hay que hablar de fidelidad en presencia de tantos ataques y amenazas. Los ataques verbales comenzaron muy pronto. "Monseñor Romero vende su alma al diablo" fue el titular de un pequeño periódico de la ultra derecha, que pronto dejó de publicarse. Las amenazas físicas a su vida vinieron después. Pocas semanas antes de su muerte se encontraron docenas de candelas de dinamila en una iglesia en la cual celebró misa, aunque no explotaron.

Mons. Romero fue consciente de que peligraba su vida, pero se mantuvo fiel, no se escondió, no llegó a componendas con nadie, ni disminuyó el volumen de su denuncia, antes al contrario. Más aún, rechazó la seguridad que le offecía el presidente de la república con estas palabras dichas públicamente en sus homilías: "quiero decirle que antes de mi seguridad personal yo quisiera seguridad y tranquilidad para 108 familias y desaparecidos... El pastor no quiere seguridad mientras no se la den a su rebaño."

A Mons. Romero comenzó a rondarle la idea de su muerte violenta, cosa nada inverosfmil, pues la muerte campeaba por El Salvador. En su último retiro espiritual, al que antes aludimos, Mons. Romero dejó por escrito to que le comunićs al P. Azcue y lo que éste le contestó.

Mi otro temor es acerca de los riesgos de mi vida. Me cuesta aceptar una muerte violenta que en estas circunstancias es muy posible, incluso el $\mathrm{Sr}$. Nuncio de Costa Rica me avisó de peligros inminentes para esta semana. El Padre me dio ánimo diciéndome que mi disposición debe ser dar mi vida por Dios cualquiera que sea el fin de mi vida. Las circunstancias desconocidas se vivirán con la gracia de Dios. El asistió a los mártires y si es necesario lo sentiré muy cerca al entregarle mi último suspiro. Pero que más valioso que el momento de morir es entregarle toda la vida y vivir para él.

Personalmente no le of hablar de estas cosas; quizás lo hiciera con otras personas. En cualquier caso siguió adelante, en el último mes que le quedaba, predicando con valentía. Después nos enteramos de que a mediados de marzo habia dicho a un periodista de Venezuela: "he sido frecuentemente amenazado de muerte." Tal como estaban las cosas en el país, con el aumento de la represión, con seis sacerdotes ya asesinados, a algunos se nos pasó por la cabeza que podian asesinar también a Mons. Romero. Pero creo que nos resistiamos a creerlo, por carifo y por la magnitud de la atrocidad; y no hablábamos de ello. El 23 de marzo escuchamos su última homilía dominical y sus palabres finales:

En nombre de Dios, pues, y en nombre de este sufrido pueblo cuyos 
lamentos suben hasta el ciclo cada día más tumultuosos, les suplico, les rucgo, les ordeno en nombre de Dios: ¡Cese la represión!

No sé si estas palabras fueron su sentencia de mucrte, pues la planificación de un asesinato profesional supongo que lleva algún tiempo. Pero de hecho culminaron el proceso de decir la verdad y de denunciar atrocidades que objetivamente lo llevó al martirio. Personalmente quedé emocionado por sus palabras, y preocupado.

El 24 de marzo, cuando ya había anochecido, sonó el teléfono de mi casa preguntando por un padre. Era yo el único que en esos momentos estaba en la casa y contesté. Me hablaba una religiosa del hispitalito, a grilos, descontrolada, casi histérica. "Han ametrallado a Monseñor. Monseñor está sangrando. "Tal era su excitación que no pude entender nada más de lo que me dijo. Tampoco le entendí si Monseñor estaba vivo o mucrto.

Salí de mi casa inmedialamente y fui a la oficina del provincial, César Jerez, a unos 50 metros. Le conté la llamada y pusimos la radio. A los pocos minutos dieron la nolicia: "Monseñor Romero ha muerto." César Jerez y yo nos quedamos un buen rato en silencio. Desupués fui a la UCA y nunca olvidaré la escena. Unas veinte personas, de vigorosa personalidad, avezadas a aguantar alaques y a escuchar malas noticias, estaban todas de pie, con cara de constemación y de abatimiento. Y en silencio. En verdad Mons. Romero había muerto. (Días más tarde me enteré que yo fui el primer sacerdote en saber la noticia. Las religiosas del hospitalito habian llamado a Mons. Ricardo Urioste, pero no pudieron localizarlo. Después llamaron a nuestra casa. Lo digo entre paréntesis, pero fue un pequefio consuelo personal: las religiosas que vivían con él nos consideraban cercanos a él.)

Las primeras horas después del asesinato me recordaron a los apóstoles después de la muerte de Jesús: abatimiento, tristeza y desconcierto. Pero muy pronto, mucho antes de los diez días que los temerosos apostoles pasaron en el cenáculo según lo cuenta san Lucas, sopló el Espíritu, y con mucha fuerza. Hubo una gran movilización: misas en su recuerdo, reuniones, comunicados, esquelas. Empezaban a llegar llamadas telefónicas de lugares distintos y distantes, periodistas, delegaciones de solidaridad. El Mons. Romero muerto, somo Jesús - asesinato y martirio-, empezaba a generar vida, en El Salvador $y$ en todas partes, entre cristianos y no creyentes. En mi experiencia no recuerdo nada semejante desde la muerte de Juan XXII. Hasta de un sindicato obrero de Checoeslovaquia llegaba la solidaridad, por mencionar sólo una entre mil anécdotas.

"Si me matan, resucitare en el pueblo salvadorefto. Se lo digo sin ninguna jactancia, con la más grande humildad," había dicho Mons. Romero pocos días antes. Y era verdad. Su entierro, el 30 de marzo, fue ante todo una formidable 
expresión de esa resurrección, una de las mayores, sino la mayor manifestación popular en la historia de El Salvador. Y, con certeza, la manifestación más sentida, más doliente y más cariñosa. Todos le lloramos de verdad - hubo unos pocos que celebraron su muerte con champán-, pero los pobres lo lloraron como sólo se llora a una madre y a un padre.

Ese 30 de marzo, nueva sangre y nuevas lágrimas en el enticro mas increible de la historia contemporánea. La tarde anterior comentábamos que algo podría pasar en el entierro, pues todavía estaba fresco el recuerdo de la masacre de una manifestación popular el día 22 de encro de ese mismo año. No hablábamos mucho de ello y queríamos convencernos de que nada pasaría. Pero pasó. Varias personas murieron asfixiadas o baleadas. Todos los obispos y sacerdotes permanecimos en catcdral para acompañar y dar alguna protección a los miles que buscaron refugio alli. iQue menos podíamos hacer para seguir los pasos de quien estábamos enterrando! Sólo el arzobispo de México y delegado papal, cardenal Corripio, salió a toda prisa hacia el aeropuerto. La muerie de Mons. Romero causó tristeza y desconcierto; su entierro causó indignación e incredulidad. Un periodista italiano lloraba; y otro periodista, creo que de un país sudamericano, me dijo mientras estábamos encerrados en catedral: "he visto muchas cosas. He estado en Viet Nam. Pero nunca he visto nada como lo de hoy." Entre tanto, el cuerpo de Mons. Romero fue enterrado a toda prisa en catedral, mientras su espíritu empezó a revolotear por el mundo entero.

Aquellos días fueron para todos nosotros de mucha agitación y trabajo. Yo empecé a escribir las primeras reflexiones sobre la vida y muerte de Mons. Romero, y ni siquiera tuve tiempo para ir a ver su cuerpo que era velado en catedral. No me era difícil describir las cosas de su vida y los detalles de su muerte, pero pronto caí en la cuenta de que al escribir sobre Mons. Romero estaba confrontado con una pregunta mucho más radical: quién fue y quién es Mons. Romero. Esta pregunta va mucho más allá de contar detalles de su vida y de su muerte. Es una pregunta por la totalidad de Mons. Romero. Es la pregunta que surge ante la muerte de Juan XXIII o de Martin Luther King. Creo que es también la pregunta - con todas las analogias del caso- de los primeros cristianos: quién fue Jesús de Nazareh quién es Jesucristo resucitado. Pronto se me hizo convicción que Mons. Romero fue un "evangelio," una buena noticia de Dios.

Habria que escribir, después, detalladamente su historia, habria que analizar, interpretar, explicar sus acciones y su pensamiento; por supuesto. Pero me convencí de que no se podía comunicar la realidad de Mons. Romero sólo a través del análisis, sin haberse dejado afectar por la totalidad de su persona. $Y$ eso dicen que son los evangelios que nos hablan de Jesús. Después de su entierro comencé a escribir un largo artículo sobre Mons. Romero que terminé el 10 de abril. Traté de analizar su persona como creyente, como arzobispo y 
como salvadoreño, y me salieron muchas páginas. Pero destrás del análisis, está el impacto global que me causó Mons. Romero. En esos días lo formulé así: "Monseñor Romero creyó en Dios." Con esa fe hizo infinidad de cosas buenas, pero en esa fe yo encontré la raíz de todo. Y esa le, para mí, lue una buena noticia, un evangelio.

Esa convicción de que no se puede comunicar quién es Mons. Romero sin dejarse afectar por él, sin captarlo como evangclio, la he comprobado muchas veces, sobre todo entre la gente pobre y sencilla. En esos días proliferaron eslampas y cartcles con su figura. Muy pronto el pueblo compuso cantos populares, corridos. Muy pronto lo llamaron pastor, profela y mártir. Pero hay algo más profundo. Varias veces he preguntado a gente sencilla, directamente y sin rodeos, quién fue Mons. Romero. La respuesta es: "Mons. Romero dijo la verdad, nos defendió a los pobres y por eso lo mataron." En estas palabras hay clarividencia, hay admiración, pero sobre todo hay amor. La gente vio en Mons. Romero alguien que en verdad los amó. $Y$ eso es una buena noticia, un evangelio.

Por esos días también recibí una carta de don Pedro Casaldáliga. Yo le había escrito a mi regreso de Sao Paulo para que escribiera a Mons. Romero dándole ánimos en su dolorosa situación intraeclesial. En la carta de respuesta don Pedro Casaldáliga estaba pascualmente gozoso -como él suele decir-, y me envió el poema ya clásico "San Romero de América." ¡Cuántas veces lo hemos leído en El Salvador con emoción! Me convencí de que don Pedro Casaldáliga captó de verdad a Mons. Romero. Escribió sobre él, afectado por él, con verdad y con amor.

Años después, en 1985, don Pedro vino a El Salvador y visitó la tumba de Mons. Romero. En la tarde, en un acto que tuvimos en la Universidad Centroamericana "José Simeón Cafias" en la capilla de Mons. Romero, nos habló de muchas cosas. Pero al final, cuando ya estaba para irse, una religiosa se levantó y le dijo: "Monsefior Casaldáliga. Muchas veces hemos lefdo su poema sobre Mons. Romero. Quisiéramos pedirle ahora que usted lo lea ${ }^{n}$ Todos nos pusimos en pie y don Pedro Casaldáliga reciló su poema. El silencio, la devoción y el gozo con que lodos lo escuchamos me convenció una vez más de que Mons. Romero seguia siendo una buena noticia. "Hoy he vuelto a rezar," me dijo un amigo al terminar el acto.

\section{IX}

La poesía de don Pedro Casaldáliga termina con estas palabras:

San Romero de América, pastor y mártir nuestro, nadie hard callar tu última homilía. 
¿Es eso verdad? No se puede dudar de que Mons. Romero se ha convertido en İgura universal. No es él, por supuesw, el único cristiano, ni siquiera el único obispo asesinado. Pero por la calidad de su vida y obra, por las circunstancias históricas de su martirio, por su increible entierro, se ha convertido en figura universal. Ha habido que ir hasta Thomas Becket, arzobispo de Canterbury -en el siglo XII- para encontrar un obispo asesinado en el altar. $\mathrm{Y}$ aun así, con una diferencia. Thomas Becket fue asesinado por defender los derechos y libertades de la Iglesia. Mons. Romero, por defender a los pobres del reino de Dios. José María Valverde, profesor de estética de la universidad de Barcelona, lo ha dicho en estos versos:

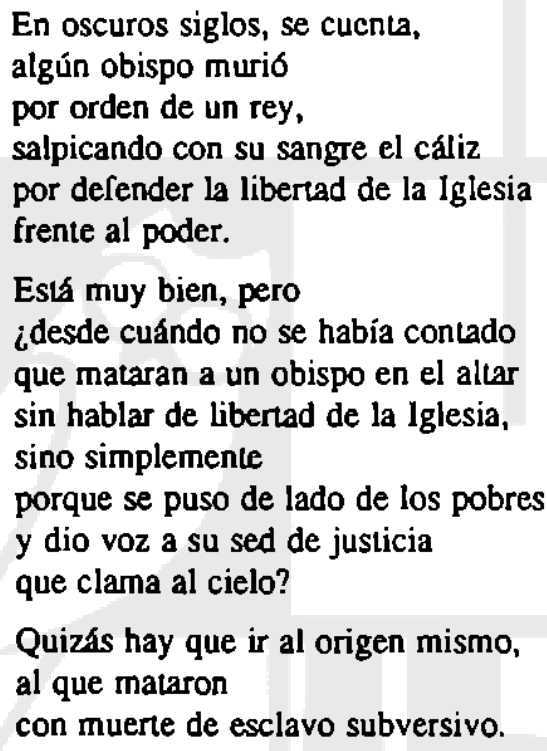

$Y$ es que el martirio de Mons. Romero y el de muchos cristianos lationamericanos se parece más que otros martirios a la muerte de Jesús. Durante un tiempo discutían algunos si se podría llamar mártir a tantos cristianos asesinados en El Salvador. En vida, el mismo Mons. Romero zanjó la cuestión:

Para mi que son verdaderos mártires en el sentido popular. Naturalmente yo no me estoy metiendo en el sentido canónico, donde ser márir supone un proceso de la suprema autoridad de la Iglesia que lo proclame márir ante la Iglesia universal.

Yo respeto esa ley y jamás diré que nuestros sacerdotes asesinados han sido mártires ya canonizados. Pero sí son mártires en el sentido popular. Son hombres que han predicado precisamente esa incardinación con la pobreza. Son verdaderos hombres que han ido a los límites peligrosos, donde la UGB (Unión Guerrera Blanca, escuadrón de la muerte) amenaza, donde se 
puede seffalar a alguien y se termina matándolo, como mataron a Cristo.

Después de la muerte de Mons. Romero se hizo inevitable confrontarse con lo que hoy es el maruirio en El Salvador y en América Latina. Si él no es un mártir cristiano ¿quién lo será? Para los pobres no hay ninguna duda; para los canonistas puede seguir habiéndola: si murió por delender la le, si murió pacientemente...K. Rahner, en un escrito de poco antes de su propia mucrte, reflexionó teológicamente sobre la necesidad de ampliar el concepto tradicional de martirio, y escribio: "¿Por qué no habría de ser mártir un Monseñor Romero, por ejemplo, caído en la lucha por la justicia en la sociedad, en una lucha que él hizo desde sus más profundas convicciones cristianas?" Me gusta intcrpretar estas palabras de K. Rahner como el elogio agradecido de un gran teólogo a un gran obispo.

Con el paso de los años la figura del máruir Mons. Romero se ha ido agigantando, pero también se ha intentado silenciarlo. Lo primero es muy claro. En El Salvador nunca ha ocurrido una cosa semejante: innumerables cantos populares, estampas, carteles, libros sobre Mons. Romero; el peregrinaje a su tumba para rezarle, pedirle favores, agradecerle. $Y$ tras estas cosas, cl amor sentido de los pobres y de todos los que desean proseguir su obra. En las reuniones de las comunidades siempre se lo recuerda y se citan sus palabras; y lo hacen con la obvia convicción de estar nombrando algo último y sagrado. Incluso ha ocurrido un fenómeno lingúístico semejante al del Nuevo Testamento. El "Seflor" es sólo Jesucristo, no hace falta especificar más. "Monsefior," a secas, es ahora Mons. Romero. Con razón dice don Pedro Casaldáliga que sería pecado querer canonizarle. El pueblo ya lo ha heho santo.

En toda América Lalina y en muchas partes del mundo Mons. Romero es admirado y querido. Gente que nunca lo vio encuentra en él una gran fucrza para su fe como creyentes y para vivir su dignidad como seres humanos. Son innumerables los comites de solidaridad y las publicaciones pastorales que llevan su nombre; los libros y artículos que reproducen sus palabras. Se han compuesto ya varias obras de teatro, una pequeña ópera y hasta una película comercial. El 24 de marzo es día sagrado en muchos lugares. El Salvador es hoy conocido en el mundo por la guerra que lo destroza, pero también por Mons. Romero. Por casualidad preguntaron una vez a alguien en un avión: ¿A dónde va usted?" "A El Salvador." "Ah, la tierra de Mons. Romero." Y como ésta, muchas anécdotas.

En estos años me ha tocado viajar con frecucncia por países latinoamericanos y europeos, Estados Unidos y Canadá. En todas partes me han pedido que les hable de él. La única vez que he estado en Asia, a donde fui con la intención de ver y callar, más que de hablar, me pidieron también que les hablara de Mons. Romero. En Tokio y en Nueva Delhi, y en muchos ouros lugares, he visto cómo Mons. Romero liene algo importante que decir a 
cristianos, marxistas, budistas e hindúes. "Les traigo una mala noticia," nos dijo un día un europeo que no recuerdo si era francés. "Mons. Romero ya no es de ustedes. Es de todo el mundo."

Algo muy hondo del ser humano y de los creyentes ha tocado Mons. Romero. Yo creo que a todos nos ofrece un camino de humanización. Nos ha ayudado a saber un poco mejor qué somos y qué debemos ser. Y a lodos nos ha ofrecido la realidad de Jesús, de Dios, para llegar a ser creyentes y humanos. Don Pedro Casaldáliga lo ha dicho lapidariamente: "la historia de la Iglesia en América Latina se divide en dos partes: antes y después de Mons. Romero."

Todo esto es para mí claro y evidente. Pero - itriste sorpresa! - empezaron a aparecer opiniones que intentaban empequefiecer su figura y silenciarlo. Mons. Romero hubiera sido un hombre bueno, dicen, pero sin muchas luces, débil y fácilmente impresionable. De ello se aprovecharon grupos radicales entre ellos los jesuítas- y lo forzaron a seguir el camino que a ellos les convenía. En otras palabras, Mons. Romero hubiera sido un fraude y ahora sería un mito mantenido artificialmente. Recuerdo mi estupor e indignación cuando, en Caracas, me contaron, en 1982, que el provincial de una congregación religiosa había oído en Roma que Mons. Romcro vino a ser un producto de la manipulación de los jesuítas. Creo que la "teoría de la manipulación" ha ido perdiendo fuerza, o al menos no se la divulga ya oficialmente, desde que Juan Pablo II visiló El Salvador en 1983. De improviso, tomando una decisión muy personal y rompiendo la ruta establecida, fue a catedral. De rodillas, rezó ante su tumba. Después, lo alabó como "celoso pastor a quien el amor de Dios y el servicio a los hemanos condujeron hasta la entrega misma de la vida de manera violenta, mientras celebraba el sacrificio del perdón y de la reconciliazión." Por lo que he oído, el Papa lo considera verdadero mártir.

De lodas formas no estará de más analizar un poco qué es lo que se esconde tras la repetida teoria de la manipulación. Para mi es claro que Mons. Romero estuvo sujeto a muchas presiones, como no podía ser menos. Sobre él ejercieron presión los gobiemos, la oligarquía, el Vaticano, la conferencia episcopal; y también quisieron inlluir sobre él los sacerdotes más avanzados y las organizaciones populares. Además, el mismo Mons. Romcro, entre los diez puntos personales que quiso analizar en su último retiro espiritual, menciona cambién el siguiente: "temo las influencias ideológicas y políticas, soy muy influenciable y son muy posibles las influencias."

Pero que estuviese sometido a presiones e influjos y que él mismo se reconociera de carácter influenciable, nada dice de que la vida y obra de Mons. Romero se deban explicar como puro producto de la manipulación. Si de presiones se trata, hay que preguntarse por que Mons. Romcro eligió la línea 
que le sugerian unos y no otros. La presión de la derecha fue más fuerte, más halagadora al principio y más amenazante después; y, sin embargo, Mons. Romero no se dejo presionar por ellos. Las presiones de la izquierda también fueron reales en algunos momentos y creo que al principio los sacerdotes avanzados deseaban y procuraban mover a Mons. Romero hacia su línea; lo cual, por otra parte, me parece legítimo. Pero ıpor qué no entender su actuación desde la explicación obvia de que Mons. Romero vio mucho más evangélica una línea que otra? Yo creo que a través de las presiones de la izquierda Mons. Romero se vio confrontado con la línea más evangélica; pero lo que le hizo ponerla en práctica no fueron las tales presiones, sino la verdad intrínseca que iba descubriendo, como he tratado de explicarlo antes al hablar de su conversión. Las presiones de la izquierda pudieron ser una ocasión de su cambio entre otras más importantes, pero no causa de su conversión; en cualquier caso, no fueron la causa fundamental.

Creo además que, sean las que fuesen las presiones de la izquierda en los comienzos, muy pronto Mons. Romero adquirió y mostró identidad propia. Lo que hizo el 19 de junio de 1977 en Aguilares no se puede en modo alguno explicar como teledirigido por otros. Era él, Mons. Romero. De tal modo que, como dije antes, desde aquel día sentí que él se nos había adelantado, que no era él el que jba siguiendo nuestros pasos, sino exactamente lo contrario.

Esto no quita que a lo largo de tres afos Mons. Romero no se sintiera muchas veces bajo presiones de unos y de otros. Tantas cosas ocurrieron, tantas fueron las decisiones que tuvo que tomar que serla una ilusión pensar que Mons. Romero actuaba como aislado en una cámara de aire incontaminado. Tampoco me parece extraflo que de vez en cuando se desahogara y dijera que se sentia bajo presiones. Supongo que eso lo haría alguna vez en privado, y me parece normal. Pero también lo hizo en público, por ejemplo en la discusión con Rogelio Ponseele que ya he mencionado. Que Mons. Romero, por lo tanto, viviera entre presiones, me parece normal. Que él mismo se reconociera impresionable por temperamento, es verdad. Pero querer deducir de ahí que su vida y obra fue producto de presiones, me parece una conclusión falta de logica en primer lugar y falsa en la realidad. Mons. Romero se reconocía impresionable, y eso lo hizo en tiempo de retiro espiritual, en un momento en que se suele analizar limitaciones y problemas con honradez. Pero, aunque él en su humildad no se lo dijese a sí mismo, era también por naturaleza emprendedor, inteligente, valiente, decidido seguidor de la voluntad de Dios. En la vida de los seres humanos - y de los santos - todos los datos de su carácter entran en juego y son puestos a producir, y a través de todos ellos llegan a ser humanos y sanlos. Querer explicar toda su vida y obra sólo desde un aspecto de su personalidad $-y$ peor, si se analiza mal- es desastroso. Es como si se dijera que san Ignacio de Loyola no pudo experimentar la gracia de Dios, pues era de caracter voluntarista, terco y tenaz. O como si se dijera de 
santa Teresa que su experiencia de Dios fue pura imaginación, pues parecía ser de carácter algo alocado.

Sea cual fuere el carácter de Mons. Romero, lo importante es analizar cómo reaccionaba, con su carácter concreto, en las decisiones que tenia que tomar en la vida real, y por qué. En lo que yo lo conocí, siempre que Mons. Romero tenia que tomar decisiones importantes las consultaba. La elaboración de las carlas pastorales llevaban infinidad de reuniones, consultas a la gente, diversos borradores, meses de trabajo. En todo ello eslaba presente Mons. Romero, preguntaba, sugeria, cuestionaba, y así se iba avanzando. Mons. Romero oraba mucho, y, al final, decidía. En la preparación de sus homilías averiguaba las cosas más importantes de la semana, consultaba cuando creía que debía tomar una postura profética y clara, conflictiva por lo tanto, aunque necesaria. Tengo el testimonio de la hermana Teresa del hospitalito de cómo solía prepararlas la víspera, la noche del sábado. Tenía sobre su mesa libros para la preparación de la explicación de las lecturas biblicas, apuntes y periódicos de la semana. Se quedaba hasta altas horas de la noche trabajando; alguna vez hasta las dos o tres de la mañana. La hermana Teresa lo veía rezar, y a la mañana siguiente predicaba la homilía. Yo creo, pues, que Mons. Romero tomaba la decisión personal última en todas las cosas importantes. Creo que con frecuencia a él mismo se le ocurría lo que tenía que hacer; otras veces se lo sugeririan otros, como es comprensible. Pero la decisión final era suya y personal.

Por qué tomaba las decisiones que tomó me parece lo más importante de analizar. $Y$ para comprenderlo me parece conveniente distinguir entre las presiones "menores" y las presiones "mayores." Las presiones menores, "categoriales," son los mil y un incidentes y contactos de la vida diaria, pláticas, discusiones, eventuales enojos, exigencias de unos y otros. Y nadie está exento de ellos en la Iglesia - desde el papa hasta el más sencillo catequista-. Pero las presiones mayores, "transcendentes," son otra cosa. Para Mons. Romero ésas fueron la voluntad de Dios y el dolor del pueblo. A mí no me cabe duda de que Mons. Romero, con la libertad que le fue dando su experiencia de Dios y su experiencia de los pobres, se dejo presionar por ellos. Si algo "manipulo" a Mons. Romero fue la gracia de Dios y el dolor de su pueblo. Estas presiones mayores son las que explican la vida y obra de Mons. Romero. Las otras, las de todos los días, forman parte de su vida, pero subordinadas a aquéllas.

Por qué se quiso reducir a Mons. Romero a un producto de la manipulación es trágico y es también claro. Los que no quieren reconocer la grandeza de su figura porque les estorba o les cuestiona tratan de buscar alguna razón para no tener que imitarlo. Buscan disculpas, nada lógicas,interesadas. $Y$ en eso también Mons. Romero me recuerda a Jesús. "Está loco," decían uno de Jesús. "Está poseído por el demonio," decían otros. "Si éste es de Nazaret, nada bueno hay que esperar," se mofaban otros. Lu que no querian era aceptar y 
seguir a Jesús de Nazaret.

También Mons. Romero reflexionó sobre ese tipo de comentarios que se hacían sobre êl. Por [ortuna lo dijo públicamnte, el 8 de julio de 1979, comentando en la homilia la suerte de los profelas.

Esto es lo terrible de la sociedad. Sociedad que rechaza la palabra del evangelio cuando no está de acuerdo con sus egoísmos, cuando no está de acuerdo con sus injusticias. Entonces surge el montón de preguntas: " $\iota Y$ de dónde le viene a éste la sabiduría? ¿Quién lo está manejando? Eso no es de él." $Y$ todas esas acusaciones tontas que, de veras, en vez de entrar adentro - ¿tiene o no tiene razón? - se quedan en un rechazo.

Es triste tener que recordar estas cosas, constatar que para algunos -especialmente cuando ocurría dentro de la Iglesia institucional- Mons. Romero sólo hubiese sido un producto de la manipulación y, ahora, un mito inflado. Y es triste, no sólo por lo injusto de la apreciación sino porque se peca contra la luz y entonces no hay solución. Si ante la aparición de una buena noticia no hay respuesta, no hay agradecimiento y no hay seguimiento, sino tergiversación y rechazo, entonces nada nos hara cambiar. Para mi Mons. Romero no es mito inflado ni producto de manipulaciones. Tuvo limilaciones, como él mismo las analiza en su retiro espiritual, limitaciones menores, muy menores desde un punto de vista espiritual y normales desde el punto de vista de la psicologia humana. Pero, también con ellas, Mons. Romero fue un salvadorefio, un creyente y un arzobispo excepcional. Sobre esto no pueden equivocarse tantas personas y personalidades que lo conocieron, tantos millones, hoy, que lo recuerdan y lo quieren. Como ya djje antes, si de manipulación se trata, creo que Mons. Romero nos manipuló a nosotros mucho más que nosotros a él.

Hoy ya no se habla mucho de esta manipulación, aunque en El Salvador Mons. Revelo, obispo de Santa Ana, la ha vuelto a sugerir. Fredy Delgado, sacerdote de la diócesis de San Vicente, acaba de publicar un panfleto lleno de falsedades donde se la vuelve a mencionar. Pero algo todavfa más triste estr ocurriendo ahora en El Salvador. se está queriendo silenciar a Mons. Romero. Mons. Romero habria sido un gran profeta, un mártir, un santo incluso - si prosperan los rumores de que se va a introducir su causa-, pero del pasado. Por triste e increible que parezca, la conferencia episcopal pera nada lo menciona en sus mensajes ni cita sus palabras para animar a los cristianos de hoy. Ahí Mons. Romero está bien enterrado.

La razón que aducen para este silencio es, de nuevo, la manipulación. Aunque ya no se recalque tanto que Mons. Romero fue, en vida, producto de la manipulación de la izquierda, se afirma ahora que la izquierda lo quiere manipular para sus intereses después de muerto. Y para evitar que eso ocurra, se somete a Mons. Romero a la más triste de las manipulaciones: el silencio. Y 
se añade: "Monseñor Romero es nuesuro."

A la pregunta "de quién es Mons. Romero" sólo se pucde responder si se analiza con honradez quién lue él. Mons. Romero fue un arzobispo, y pertenece a la Iglesia jerárquica; fue un cristiano, y perenece a lodos los cristianos; fue un salvadoreño, y pertenece a todos los salvadoreños. Fue insignemente las tres cosas, y por ello a él se pueden remitir - y ojalá lo hagan todos- jerarcas, cristianos y salvadoreffos. Pero remitirse a Mons. Romero no significa considerarlo como propiedad privada, ni menos como el talento de la parábola que se guarda para no perderlo. Significa dejarse poseer por él, ponerlo a producir.

Aquí en El Salvador son muchos los que lo recuerdan, lo quieren y lo reclaman: comunidades de base y grupos de sacerdotes y religiosas, sindicalistas y hasta combatientes del FMLN -el 24 de marzo se celebra en los campamentos. A algunos no les gusta que las cosas sean así, pero así son, y hay que preguntarse si es bueno o malo que así sean. A mi juicio, siendo Mons. Romero hombre de Dios y hombre de este mundo, preclaro creyente y preclaro salvadoreño, todos aquellos que sienten de verdad la fe y la realidad de este mundo tienen derecho a invocarlo, recordarlo y celebrarlo como suyo. $Y$ en ello no hay manipulación, mientras recordar una de sus dimensiones no signifique rechazar la otra. Otra cosa es quiénes pueden reclamar a Mons. Romero con mayor derecho y mayor necesidad. Estos son los que lo invocan como cristiano y como salvadorefio: son los salvadoreffos, pobres y cristianos, que encuentran en él una luz y una esperanza que no encuentran en otras partes, y quienes aman de verdad a Mons. Romero porque él en verdad los ań a ellos.

La manipulación de Mons. Romero se da cuando sólo se toma una de sus dimensiones y se rechaza la otra. Pero todavía peor, cuando se lo silencia, como si Mons. Romero nada tuviera que decir y que ofrecer ya al país y a la Iglesia. Periódicamente se anuncian investigaciones sobre los autores de su asesinato, pero con ello no se hace más que dar vuelta a su cadáver, no a su vida. Además de la hipocresía de querer mostrar, triunfalistamente, que el gobiemo ha aclarado este crimen - cuando guarda silencio sobre los otros 60.000 - además de la manipulación de ofrecer los resultados de las investigaciones durante las campafas polfticas - con lo cual un partido, el que acusa, quiere sacar ventaja sobre otro, el acusado-, lo peor es que dando vueltas alrededor de su cad́́ver se silencia al Mons. Romero vivo, iluminador, inspirador. ¿Nada tiene que decir hoy Mons. Romero sobre la vida y la muerte de los salvadorefios, sobre la guerra y la paz, sobre la justicia y la reconciliación? Ni una palabra recuerdan de él los gobernantes, la asamblea, los políticos, la Fuerza Armada y la embajada de Estados Unidos. ¿Nada tiene que decir Mons. Romero sobre la fe, la esperanza y el compromiso de los cris- 
Lianos, sobre la vida sacerdotal y parroquial, sobre la profecía y la misericordia? Mons. Rivera, el único obispo que le fue fiel en vida, lo cila algunas veces. Su urabajo por el diálogo y la negociación, si cooperación para la humanización dcl conflicto y para aliviar sus consecuencias, su defensa de la Oficina de Tutela Legal del Arzobispado, reflejan algo de la inspiración de Mons. Romero. Pero la conferencia episcopal, los planes pastorales diocesanos, donde los hay, lo ignoran. Este es el entierto más triste de Mons. Romero.

Pero Mons. Romero sigue vivo. Vive en los que le van a rezar en catedral y en el fondo de sus corazones. Vive en refugios y repoblaciones, en los cantones y en las champas de los tugurios. Vive en algunos conventos, en algunos profesionales, en algunos intelectuales; en la UCA, se pueden ver por todas partes carteles de Mons. Romero. Para mí no hay duda de que Mons. Romero vive en los pobres para quienes la vida, sobrevivir, sigue siendo su tarea fundamental; vive en todos aquellos que toman la decisión de servir a la vida de esios pucblos y de su recuerdo sacan fortaleza para correr los riesgos. Y vive en todos aquellos que buscan a Dios, con sinceridad, a veces a tientas, a veces con gozo. Mons. Romero sigue iluminándoles ese misterio de Dios, tan opacado en la crucifixión de los pobres y an luminoso en su esperanza y en su compromiso por la resurtección.

\section{$\mathbf{X}$}

Estos son mis recuerdos de Mons. Romero. He mencionado sólo algunos, los que para mí son más importantes, los que más me han iluminado y animado. Otras personas pueden compartir estos recuerdos; otros tendrán recuerdos diferentes, quizás más importantes. Creo que el recuerdo fundamental es el de los pobres -en cuyo interior no puedo entrar en definitva. Si juntásemos todos los recuerdos de Mons. Romero, si se contasen uno por uno, como dice san Juan al terminar su evangelio, "pienso que ni todo el mundo bastaria para contener los libros que se escribieran."

Quiero aradir que estos recuerdos no los ofrezco en actitud de panegírico, sino con lotal sinceridad. Un nuncio me dijo una vez que en mis escritos alababa en exceso a Mons. Romero. Yo pienso que no es asi, objetivamente; y ciertamente no es ast en mi intención. Pero no puedo negar el impacto profundo que me causó Mons. Romero.

Quiero también afiadir que Mons. Romero no es mi único recuerdo de estos antos excepcionales en El Salvador. Recuerdo a Rutilio Grande y a muchos otros, sacerdotes, religiosas, campesinos, sindicalistas, estudiantes, que fueron también asesinados por causa de la justicia; la muerte de algunos de ellos, entre torturas, fue más dolorosa que la de Mons. Romero. Recordar a Mons. Romero no significa, pues, aislarto de los demás mártires, ni exaltarlo de tal manera que los otros queden en la penumbra. Recordar a Mons. Romero es más bien re- 
cordar a muchos otros, mantener vivos a tantos profetas y mártires, campesinos y delegados de la palabra. Es, sobre todo, recordar a miles de mártires inocentes, indefensos y sin nombre; es recordar a todo un pueblo crucificado, cuyos nombres nunca se conocerán públicamente, pero que están integrados para siempre en Mons. Romero. En vida fue "voz de los sin voz." En muerte es "nombre de los que han quedado sin nombre." Dios quiera que un día se canonice a "Monsefior Romero y márires salvadoreños," a "Monseffor Romero y mártires latinoamericanos."

Quiero decir, para terminar, que mis recuerdos de Mons. Romero sólo tienen sentido dentro de un único y gran recuerdo, el del Mons. Romero total. Los recuerdos que he ofrecido no son, pues, elementos para reconstruir, después, su vida y su figura; no son como las piezas de un rompecabezas que se van uniendo hasta llegar a mostrar un cuadro. Al contrario; para mi el cuadro ha estado muy claro desde el principio; las piezas individuales, las he podido describir más o menos adecuadamente, aunque he intentado hacerlo con honradez. Otros podrán aporar otras piezas, analizar o incluso discutir las piezas que yo he presentado.

¿Cómo formular en una palabra a ese Mons. Romero total? ¿Cómo conlestar, en una palabra, quién fue Mons. Romero? Como en el Nuevo Testamento, después de la muerte y resurrección de Jesús, puede haber preferencias: unos lo llamaron el mesfas, otros el Hijo de Dios, otros la palabra de Dios; y todos tenían razón. A Mons. Romero lo hemos llamado pastor, profeta, mártir, preclaro creyente y preclaro salvadorefto. Si he de poner en una palabra la verdad que se expresa en esos títulos, yo me dicido por la siguiente: Mons. Romero fue "una buena noticia de Dios a los pobres de este mundo," y, desde los pobres, a todos. Dicho de otra forma, todavía más radical desde un punto de vista teológico, quiero concluir con las palabras del P. Ignacio Ellacuría en la misa que tuvimos en la UCA pocos días después de su martirio y que se me quedaron grabadas: "con Monsefior Romero Dios pasó por EI Salvador." 